\title{
Effect of operating temperature on degradation of solder joints in crystalline silicon photovoltaic modules for improved reliability in hot climates
}

\author{
Osarumen O. Ogbomo ${ }^{1 *}$, Emeka H. Amalu², N.N. Ekere ${ }^{1}$, P. O. Olagbegi ${ }^{3}$ \\ ${ }^{1}$ School of Engineering, Faculty of Science and Engineering, University of Wolverhampton, WV1 1LY, UK \\ ${ }^{2}$ Department of Engineering, School of Science, Engineering and Design, Teesside University, \\ Middlesbrough, Tees Valley, TS1 3BA, UK \\ ${ }^{3}$ Mechanical Engineering Department, Faculty of Engineering, University of Benin, Nigeria \\ “Email Address: O.O.Ogbomo@wlv.ac.uk, ogbomoosarumen@yahoo.com
}

\begin{abstract}
Accelerated degradation of solder joint interconnections in crystalline silicon photovoltaic (c-Si PV) modules drives the high failure rate of the system operating in elevated temperatures. The phenomenon challenges the thermo-mechanical reliability of the system for hot climatic operations. This study investigates the degradation of solder interconnections in c-Si PV modules for cell temperature rise from $25^{\circ} \mathrm{C} \mathrm{STC}$ in steps of $1{ }^{\circ} \mathrm{C}$ to $120^{\circ} \mathrm{C}$. The degradation is measured using accumulated creep strain energy density $\left(W_{a c c}\right)$. Generated $W_{a c c}$ magnitudes are utilised to predict the fatigue life of the module for ambient temperatures ranging from European to hot climates. The ANSYS mechanical package coupled with the IEC 61215 standard accelerated thermal cycle (ATC) profile is employed in the simulation. The Garofalo creep model is used to model the degradation response of solder while other module component materials are simulated with appropriate material models. Solder degradation is found to increase with every $1^{\circ} \mathrm{C}$ cell temperature rise from the STC. Three distinct degradation rates in $\mathrm{Pa} /{ }^{\circ} \mathrm{C}$ are observed. Region 1,25 to $42^{\circ} \mathrm{C}$, is characterised by degradation rate increasing quadratically from 1.53 to $10.03 \mathrm{~Pa} /{ }^{\circ} \mathrm{C}$. The degradation rate in region 2,43 to 63 ${ }^{\circ} \mathrm{C}$, is critical with highest constant magnitude of $12.06 \mathrm{~Pa} /{ }^{\circ} \mathrm{C}$. Region 3,64 to $120^{\circ} \mathrm{C}$, demonstrates lowest degradation rate of logarithmic nature with magnitude 5.47 at the beginning of the region and $2.25 \mathrm{~Pa} /{ }^{\circ} \mathrm{C}$ at the end of the region. The module fatigue life, $L$ (in years) is found to decay according to the power function $L=721.48 T^{-1.343}$. The model predicts module life in London and hot climate to be 18.5 and 9 years, respectively. The findings inform on the degradation of c-Si PV module solder interconnections in different operating ambient temperatures and advise on its operational reliability for improved thermo-mechanical design for hot climatic operations.
\end{abstract}

\section{Key words}

Solder joint degradation, hot temperature climates, operating temperature, ambient temperature, PV reliability, PV solder joints, accelerated degradation, accumulated strain energy, cell temperature, fatigue life. 


\section{Introduction}

The annual electrical power consumption of the entire planet can be generated by the sun in just one hour (Harrington, 2015; Maehlum, 2013). Solar energy is abundant in addition to being clean, sustainable and renewable (Belward et al., 2011; Gujba et al., 2011). However, some parts of the world are still struggling to meet their energy needs. Photovoltaic module (PVM) systems are capable of harnessing and converting the immense energy of the sun into useful electricity. Unfortunately, PVMs have demonstrated low performance in hot climates because elevated ambient temperature conditions significantly influence their performance. The conditions include the intensity of solar radiation, cell temperature magnitude, wind speed and humidity (Dubey et al., 2013; Skoplaki and Palyvos, 2009a, 2009b). Normally, PV modules are designed to operate under standard test conditions (STCs) which are solar radiation of $1000 \mathrm{~W} / \mathrm{m}^{2}$, cell temperature of $25^{\circ} \mathrm{C}$, wind speed of $1 \mathrm{~m} / \mathrm{s}$ and air mass (AM) of 1.5. Cell temperature of $25^{\circ} \mathrm{C}$ is characteristic of European and other temperate climates. The operating conditions of PVMs in hot climate differ from STC and vary in different climatic zones (Eludoyin et al., 2014). High cell and ambient temperatures are considered critical to the reliability of PV solder interconnections.

This study focuses on hot climates with high ambient temperatures ranging from $25^{\circ} \mathrm{C}$ to $45^{\circ} \mathrm{C}$ which can force PV cell temperatures to increase to as high as $90^{\circ} \mathrm{C}$. Kurnik et al. (2011) in their outdoor testing of PV module temperature and performance under different mounting and operating conditions, reported that the temperature difference between ambient and module can be as high as $22{ }^{\circ} \mathrm{C}$. The PV module has been described as a layered composite of different materials hence the different material combinations complicate stress distribution and concentration (Lenarda and Paggi, 2016; Ojo and Paggi, 2016a). Operations at high-temperatures increases the mismatch effect among crystalline silicon wafer, silver contacts, solder, copper ribbons and other component layers in the module occasioned by the differences in their coefficient of thermal expansion (CTE). In turn, the mismatch leads to thermo-mechanical induced fatigue loading of the interconnection in the PV module (Dubey et al., 2013; Kato, 2012). Consequently, PV modules operating in the hot climatic regions possess higher failure rates than those in temperate climates. Munoz et al. (2011), in their measurement of early degradation of crystalline silicon PV modules using visual inspection, I-V curve characteristics, thermal evaluations by Infrared imaging and electroluminescence, reported that early defects are caused by module operation in conditions that differ from standard test conditions.

Ferrara and Philipp (2012) in their study of the reasons for PV module failures, grouped them into intrinsic and extrinsic factors. Intrinsic factors are based on material properties while extrinsic factors are based on climatic stress factors and defective installations. Highlighted climatic stress factors which include solar irradiation, humidity, wind, high/low 
temperatures and temperature changes result in failure modes that can either be obvious to an observer or not. Obvious failures like discoloration, delamination, formation of bubbles and cracking of EVA showed no direct relation to power loss whereas, cell and interconnection breakage are responsible for the degradation of electrical performance of PV modules as well as reduction in fatigue life and lifespan. Solder interconnections perform structural and electrical functions in a PV module. Any degradation in the solder joint means the power generated by the PV cell cannot be accessed. Additionally, the solder joint holds the electrical components (i.e. PV cell, contact and interconnect ribbons) of PV modules together.

Ndiaye et al. $(2013,2014)$ buttressed on the economic importance of PV module fatigue life and lifespan. They indicated that in the choice of energy sources, consumers consider cost effectiveness and return on investment, so fatigue life and lifespan are determining factors. Further findings from their review of silicon photovoltaic module degradation in Senegal, includes identifying temperature and humidity as the most dominant factors responsible for all observed modes of PV module degradation of which interconnection breakage topped the list. They also reported that current literature on PV module degradation focuses on the degradation of the entire module and not on a single mode of degradation. They recommended that in the study of PV module degradation, one mode of degradation should be focused on at a time as this will provide better understanding and thorough research.

The majority of previous literature (Jordan et al., 2010; Jordan and Kurtz, 2013; Kurnik et al., 2011; Skoplaki et al., 2008; Ye et al., 2014) have studied the electrical power degradation of $\mathrm{PV}$ modules considering various component parts but have neglected the effect of solder joints degradation. The PV failure modes observed in field operations include delamination and discolouration of EVA, solder bond and ribbon degradation and cracking as well as burn marks (Bosco, 2010; Marc Köntges et al, 2014). Other researchers which include Jeong et al., (2012); Zarmai et al., (2015) reported that the solder interconnection is the most susceptible part of the PV Module and responsible for over $40 \%$ of module failures. Chandel et al. (2015), in their degradation analysis of 28year field exposed mono-c-Si photovoltaic modules directly coupled with solar water pumping system in western Himalayan region of India, reported that interconnection degradation is responsible for increase in shunt and series resistances which imply decrease in short circuit current and power output of PV Module. They further argued that contact and interconnection degradation are the primary degradation modes of PV modules operating in tropical climates - known for their hot and humid characteristics.

Figure 1 presents a schematic showing the operation of a PV module in hot climate. The PV module functions to harness only the light energy of the sun into useful electrical power - which is the functional design. However, field operations in a hot climatic region exposes the module to both the heat and light energies of the sun. Such operation exposes the module to conditions outside its designed intents. The figure shows that the PV module converts the light energy into useful electrical power, but the unwanted heat 
energy impedes power generation and accelerates the interconnection degradation which leads to interconnection rupture.

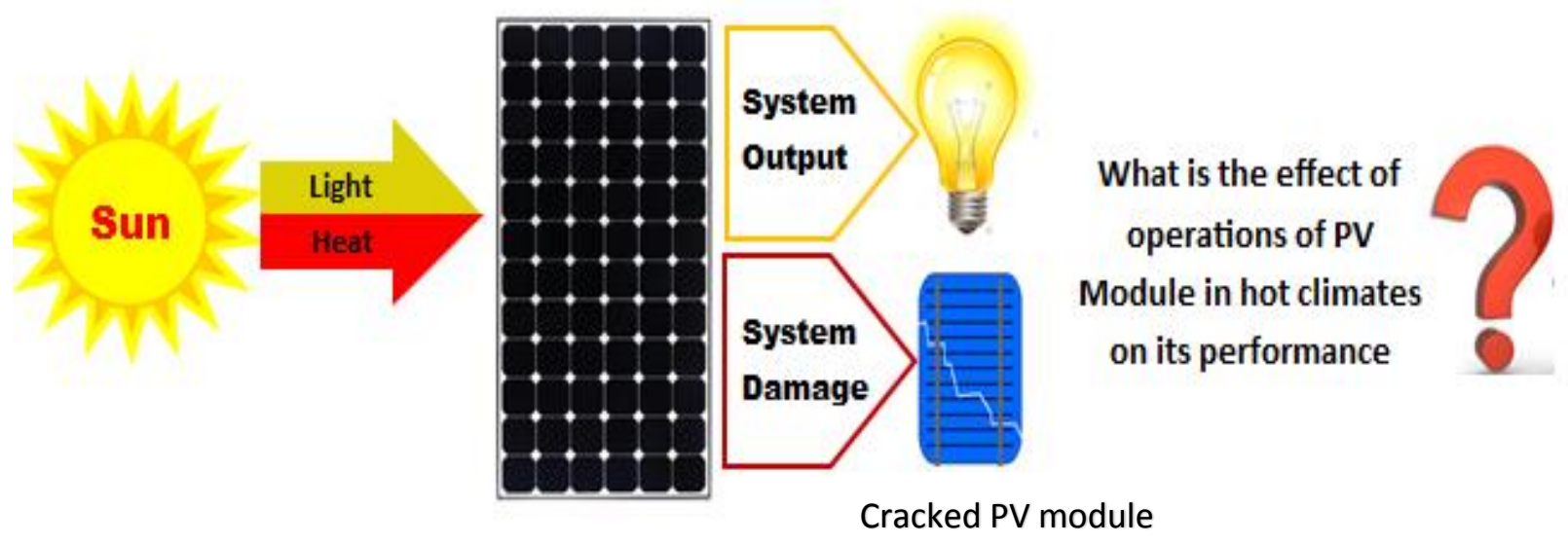

Fig. 1: Schematic showing the operation of PV modules in hot climate

The significant effect high temperature operation has on the electrical conductivity of the solder interconnection and thus power output of the entire PV module is buttressed in our previous study (Ogbomo et al., 2017). In that study, the performance of PV module contacts and interconnection technologies in tropical climate were scrutinised. At high temperatures, electrons in the material are thermally excited and energised thus, they vibrate and collide with one another. This activity increases the electrons' resistance to the flow as electric current and impedes the electrical conductivity of the material. This implies that as temperature increases, resistivity and electrical resistance increase. These relations are represented in Eqs. (1) and (2). As a result of the inverse relationship between electrical resistance and electric current, an increase in resistance leads to a corresponding decrease in current and hence power output. Equations (3) and (4) represent these relations.

$\rho=\rho_{0}[1+\alpha(d T)]$

$R=R_{0}[1+\alpha(d T)]$

$I=\frac{V}{R}$

$P=I^{2} R$

Where $\rho_{0}$ is initial resistivity $(\Omega \mathrm{m}), \rho$ is final resistivity $(\Omega \mathrm{m}), R_{0}$ is initial resistance $(\Omega)$, $R$ is final resistivity $(\Omega), \alpha$ is temperature coefficient of resistivity $\left(\mathrm{K}^{-1}\right)$ and $d T$ is temperature change $(\mathrm{K})$. I is electric current (amp.), $\mathrm{V}$ is voltage (volts) and $\mathrm{P}$ is electrical power (watts).

Although there are literature on the electrical power degradation of PV module which include (Bastidas-Rodriguez et al., 2017; Jordan et al., 2017; Sander et al., 2010), the 
present study focuses on the thermo-mechanical degradation of the PV solder interconnections in high temperature climates. The effect of non-STC operating temperatures on the PV module performance and reliability is critical and drives the module high failure rate in hot climate. There is therefore the need to critically investigate the effect of operations of PV modules in hot climate on its performance with focus on solder interconnection reliability. The rationale to investigate the degradation for every $1^{\circ} \mathrm{C}$ rise from STC is borne out of the realisation that Dubey et al. (2013) and Kato (2012) reported that the temperature coefficient pMax of crystalline silicon PV modules is $-0.5 \%$. Implying that for every $1^{\circ} \mathrm{C}$ rise from the STC, the power conversion efficiency (PCE) of the PV module decreases by $0.5 \%$. This observation necessitates urgent research to ascertain the relationship between operating temperature and thermo-mechanical degradation of PV solder joints, hence provide information to improve the performance and reliability of PV module in hot climate. The claim is strengthened by the reports of (Huld et al., 2010; Hussein et al., 2004; King et al., 2002; Obinata et al., 2010; Pacca et al., 2007; Woyte et al., 2013) that the deviation of modules cell and ambient temperatures in the hot climate from the STC calls for research aimed at providing more information to predict the performance and fatigue life of modules in the climatic zone accurately.

This study aims to investigate the effect of high-temperature on degradation of solder joints in photovoltaic module for improved reliability in hot climate. In addition, the research seeks to identify the numerical relationship between cell temperature rise from STC and the solder joint degradation.

\section{Thermal Load}

Studies report that operations of crystalline silicon PV (c-Si PV) module in hot climate is characterised with high failure rates that results in short fatigue lives and lifespan of the module. These high failure rates are attributed to deviant operating conditions in hot climates from the STCs. The operating PV cell temperatures in the tropics can be as high as $90^{\circ} \mathrm{C}$. In a previous research (Ogbomo et al. 2017) on PV module technologies for increased performance in tropical climate, cell, contact and solder interconnection technologies are investigated. The low performance of crystalline silicon PV modules in hot climates was highlighted hence the authors proposed that a PV module comprised of Cadmium Telluride cell, back contact and back-to-back solder interconnection is better performing in hot climate when measured on energy payback time, contact recombination losses and thermo-mechanical reliability of solder interconnection. However, with crystalline silicon PV modules still possessing about $84 \%$ of total market share and Cadmium Telluride only 6\%, c-Si PV modules remain the utmost interest (Ogbomo et al., 2017). Several reasons account for the dominance of c-Si PV modules over Cadmium Telluride PV modules in the market. Some of which include C-Si PV modules being around longer and are ahead of the others in research and development. The others being considerations on the cost of raw materials and toxicity of elemental Cadmium. 
The c-Si PV modules comprise different materials with respective material properties. These materials include silicon cell, silver contacts, copper ribbon interconnects, glass, EVA encapsulant and Tedlar back sheet. Of these component parts, the solder interconnection has been reported as the most susceptible part of the module and responsible for over $40 \%$ of failures (Dubey et al., 2013; Kato, 2012; Jeong et al., 2012; Zarmai et al., 2015). The susceptibility of the solder interconnections - which comprises silver contact bonded to copper ribbon interconnects via lead free solder - is linked to the mismatch between the coefficients of thermal expansions (CTE) of the bonded materials in the solder joint. The bonded materials in the solder joint expand and contract at different rates during field operation. The deformation leads to crack formation, crack propagation and eventual failure of the solder joint and the PV module. Ike (2013) measured the effect of temperature on the performance of PV solar systems operating in eastern Nigeria for a year. He reported a proportionality between power output and ambient temperature and suggested that PV systems be installed where air currents can keep ambient temperatures low to increase power output.

The thermal load conditions applied for the investigation are presented in sections 2.1 and 2.2. Section 2.1 discusses the thermal load applied on the PV module with every step rise of cell temperature from STC while section 2.2 focuses on the thermal load due to temperature cycling.

\subsection{Step rise thermal load, $\mathrm{T}$ for $25^{\circ} \mathrm{C} \leq \mathrm{T} \leq 120^{\circ} \mathrm{C}$}

The degradation of solder joint is determined at each $1^{\circ} \mathrm{C}$ temperature rise from $25^{\circ} \mathrm{C}$ STC. To fully understand and quantify the effect of high temperature on PV solder joint degradation, the relationship between solder joint degradation and each $1^{\circ} \mathrm{C}$ rise in $\mathrm{C}-\mathrm{Si}$ PV cell temperature from STC is described numerically. For each $1^{\circ} \mathrm{C}$ step rise from $25^{\circ} \mathrm{C}$ STC, the corresponding value of solder joint degradation is generated from the simulation output. Applied PV cell temperature loads range from $25^{\circ} \mathrm{C}$ to $120{ }^{\circ} \mathrm{C}$. Section 4.1 presents the results and discusses the effect of step cell temperature rise on solder joint degradation using equivalent stress, equivalent strain and maximum strain energy density. The numerical relationship and graphical plots between PV cell temperature and solder joint degradation are then presented.

\subsection{Thermal Cycling}

The actual operating temperature condition of a PV module is better described by a temperature cycle where temperatures continuously rise and fall over the lifetime of the module. The IEC 61215 standard (Arndt and Robert Puto, 2010) utilised for the fatigue life tests and lifespan tests of crystalline silicon PV module is applied. Figure 2 is a plot of the applied thermal load profile showing plot of temperature against time. The current IEC 
61215 standard test employs a thermal load profile commencing at $25^{\circ} \mathrm{C}$. The hot (or high) dwell is set at $85^{\circ} \mathrm{C}$ while the cold (or low) dwell is at $-40^{\circ} \mathrm{C}$. The ramp rate is 1.667 ${ }^{\circ} \mathrm{C} / \mathrm{min}$, upper and lower dwell times are 10 minutes each for 200 cycles at a standard ambient operating temperature of $25^{\circ} \mathrm{C}$. For this study, the ambient temperature has been varied from $25{ }^{\circ} \mathrm{C}$ to $45{ }^{\circ} \mathrm{C}$. Previous researchers (Amalu and Ekere, 2012a, 2012b) studied flip chip solder joints and applied thermal cycling with high dwell as high as 157 ${ }^{\circ} \mathrm{C}$ and cold dwell of $-38^{\circ} \mathrm{C}$ with ramp rate of $15^{\circ} \mathrm{C} / \mathrm{min}$. For c-Si PV module solder joints, the IEC 61215 standard with steady ramp rate of $1.667^{\circ} \mathrm{C} / \mathrm{min}$ demonstrates closer real life operational temperatures.

In addition to solder interconnection degradation, cyclic loading has been reported to cause the deformation of various component layers in the PV module thereby impeding the performance of the system. Paggi et al., (2014), in their study on the fatigue degradation and electric recovery in silicon solar cells embedded in photovoltaic modules, postulated that cyclic loads which caused cracks in the silicon cell layer of PV modules are responsible for $10 \%$ of field failures and result in electrical performance degradation. Electrical performance degradation is measured by parameters including increase in series and shunt resistance, decrease in electric current and power output. They reported that silicon cell cracking led to $7 \%$ increase in series resistance, $4 \%$ power output loss and $3 \%$ decrease in fill factor. These parameters for electrical performance degradation are measured experimentally utilising cyclic bending tests and non-destructive monitoring techniques like electroluminescence and thermal infrared imaging. Our present study focuses on the thermo-mechanical degradation of solder interconnections which is responsible for over $40 \%$ of PV module field failures. Creep strain energy values and fatigue life predictions under non-STC loads, which are obtained in ANSYS finite element modelling environment, are utilised for our investigation.

Section 4.2 further discusses the solder joint degradation under the thermal cycling load. Equivalent stress, equivalent strain and accumulated creep strain energy density are the parameters used to quantify solder joint degradation. Fatigue lives under the various ambient temperatures are also predicted. 


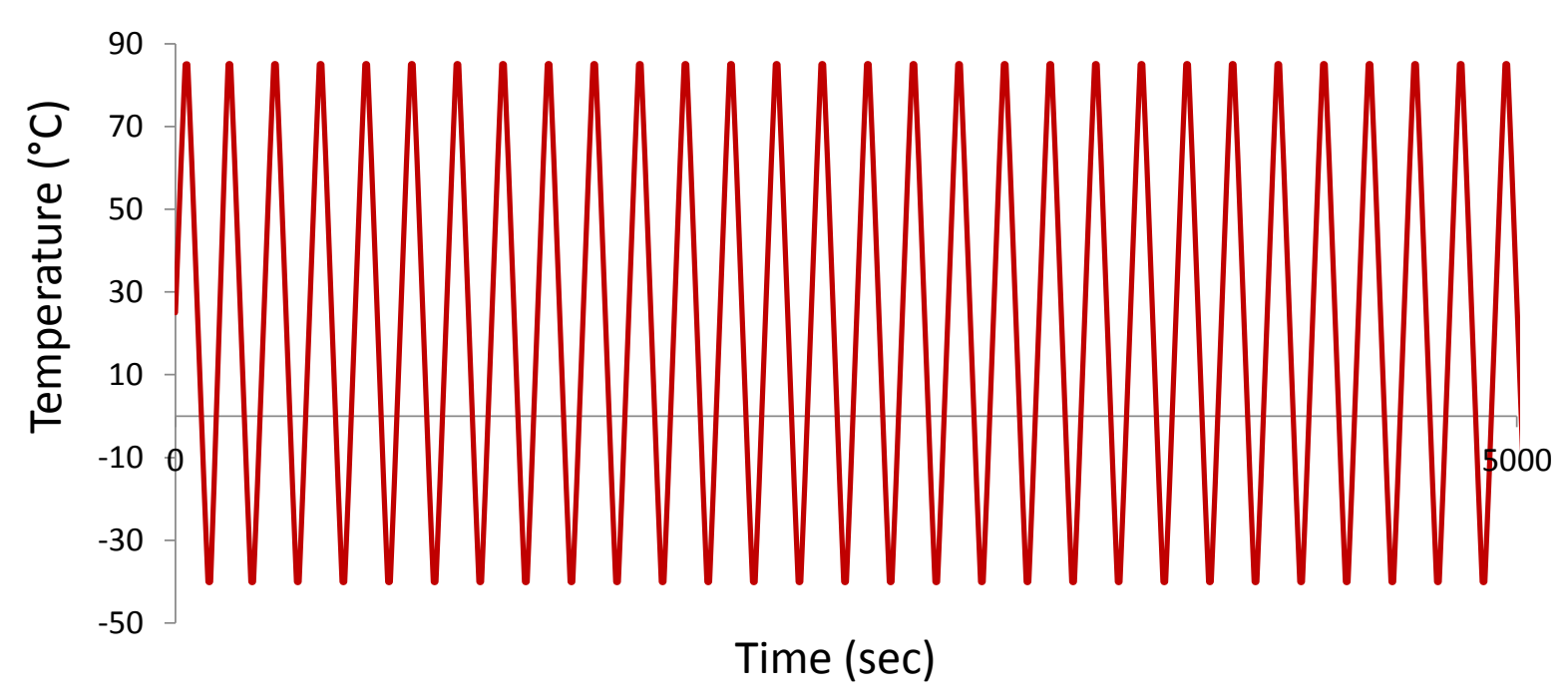

Fig. 2: Thermal Cycle Loading showing temperature $\left({ }^{\circ} \mathrm{C}\right)$ against time $(\mathrm{sec})$

\section{Finite Element Analysis}

Finite element modelling (FEM) is employed to investigate the effect of non-standard ambient and cell temperatures on the degradation of c-Si PV solder interconnections. In recent years, FEM has been utilised to investigate parameters that would otherwise be expensive and time consuming to investigate using laboratory experiments. These experiments can take several years and a lot of money when performed in laboratory. SolidWorks package is used to design the Finite Element (FE) model while ANSYS mechanical package is utilised to simulate the response of the FE model to the applied loads. Solder joint damage is quantified by accumulated creep strain energy generated from the ANSYS FEM.

Section 3.1 presents and discusses the material properties in the FE model while section 3.2 describes the FE modelling and methodology.

\subsection{Materials and their Properties}

The PV module architecture from top-to-bottom comprises glass, EVA encapsulant, copper ribbon interconnect, solder, silver front contact, crystalline silicon wafer, aluminium back contact and Tedlar back sheet. PV solder interconnection consist of copper ribbons joined to silver contacts by $\mathrm{Sn} 3.5 \mathrm{Ag} 0.5 \mathrm{Cu}$ solder alloy. The interconnection is shown in Fig. 6. The various component layer materials in the PV module and their respective properties are presented in Table 1. The table shows properties which include coefficient of thermal expansion (CTE), Young's Modulus and Poisson Ratio. These properties constitute part of the input for the ANSYS FEM analyses. Material components are modelled using linear elastic, viscoelastic and temperature dependent material properties. 


\subsection{Finite element modelling and methodology}

The PV module component layers with respective dimensions are shown in Table 2. Figure 4 shows different views of the PV module architecture with component layers from the SolidWorks software environment. The PV module architecture from SolidWorks is converted to an acceptable format which forms the geometry input for ANSYS FEM environment. In ANSYS, all the respective material properties of component layers in the PV module are inputted as Engineering Data. Lenarda and Paggi, (2016), proposed a geometrical multi-scale numerical method for coupled hygro-thermo-mechanical problems in photovoltaic laminates. They presented advanced model schemes of imperfect sealing between PV component layer interfaces. These interfaces that can debond thereby allowing moisture diffusion and chemical oxidation, require much finer mesh sizes to handle non-linearities of the problem. In our present study, all the interfaces between the component layers are assumed to be fully bonded with perfect adhesion, deformation is shear free and one dimensional, and the fixed support is on the Tedlar back sheet layer. Utilising a less advanced model and in neglecting non-linearities, our finite element investigation is represented by a relatively coarse mesh model as presented in Figs. $5 b$ \& $6 b$.

The residual stresses accumulated in the PV module during encapsulation, especially, have been studied. Ojo and Paggi, (2016b) predicted residual compressive stresses between $40 \mathrm{MPa}$ and $60 \mathrm{MPa}$ in photovoltaic modules after lamination utilising a thermoviscoelastic shear-lag model. In their later study (Ojo and Paggi, 2016a), a 3D coupled thermo-viscoelastic shear-lag formulation for the prediction of residual stresses in photovoltaic modules after lamination, they observed mean compressive stresses between $40 \mathrm{MPa}$ and $65 \mathrm{MPa}$ at the edges of the silicon cell, and $140 \mathrm{MPa}$ at the centre. In our present investigation, the focus is on the degradation of solder under non-STC temperatures and so the variations in stress and strain from the initial configuration (i.e. STC conditions) are considered only. Hence the residual stresses have been assumed to be negligible since the absolute values of stress and strain are not taken into consideration.

Equation (5) presents the Garofalo creep model (Dudek et al., 2003). Where, $\varepsilon_{c r}$ is the creep strain rate, $\mathrm{C}_{1}, \mathrm{C}_{2}, \mathrm{C}_{3}, \mathrm{C}_{4}$ are the Garofalo creep parameters for SnAgCu solder, $\sigma$ is the equivalent Von Mises Stress and $\mathrm{T}$ is the absolute temperature.

$$
\varepsilon_{c r}=C_{1}\left[\sinh \left(C_{2} \sigma\right)^{C_{3}} \exp \left(-\frac{C_{4}}{T}\right)\right.
$$

Garofalo creep model was utilised to simulate the degradation response of solder while other material responses were modelled using appropriate models. Garofalo creep model is used to determine the maximum creep strain energy density which measures the solder joint damage. Table 3 presents the Garofalo creep constants $\left(C_{1}, C_{2}, C_{3}\right.$, and $\left.C_{4}\right)$ employed. Further discussions on creep strain energy density are carried out in section 4. 
Syed $(2004,2001)$ extensively studied fatigue life prediction of SnAgCu flip chip ball solder joints in printed circuit boards (PCBs). Equations (6) and (7) represent fatigue life prediction utilising accumulated creep strain and accumulated creep strain energy density, respectively. The constants of fatigue life prediction ( $\mathrm{C}$ and $\mathrm{W}$ ) were derived after linear multiple regression analysis of the hyperbolic sine and double power law constitutive creep models.

$$
\begin{aligned}
& N_{f}=\left(C \varepsilon_{a c c}\right)^{-1} \\
& N_{f}=\left(W \omega_{a c c}\right)^{-1}
\end{aligned}
$$

Where $N_{f}$ is the Mean Fatigue Life (cycles), $\varepsilon_{a c c}$ is the accumulated creep strain per cycle, $\omega_{a c c}$ is the accumulated creep strain energy density per cycle, and the constants of fatigue life prediction are $\mathrm{C}=0.0405$ and $\mathrm{W}=0.0014$.

Several studies have been published on the fatigue life assessment of ball solder joints in PCBs and other surface mount electronics (Menka et al., 2011; Mi et al., 2014; Syed, 2004, 2001; Wang and Wu, 2011; Wong et al., 2016; Zhao et al., 2002) but there is none on composite solder joints in PV modules especially under various non-standard ambient and cell temperatures. Our study applies hyperbolic sine creep model and accumulated creep strain energy density for the fatigue life prediction of composite PV solder joints under non-standard ambient temperatures.

Equation (8) presents the relation between creep strain energy and creep strain energy density. Where $E$ is the maximum creep strain energy density $(\mathrm{Pa}), E_{c}$ is the maximum creep strain energy per cycle (Joule) and $V$ is the solder volume $\left(\mathrm{m}^{3}\right)$.

$E=\frac{E_{c}}{V}$

The accumulated creep strain energy density (i.e. measure of solder damage) is derived from the relations in Eqs. (9) and (10).

$E_{A}=\sum_{i=1}^{n}\left|E_{i}-E_{i+1}\right|$

$\sum_{i=1}^{n}\left|E_{i}-E_{i+1}\right|=\left|E_{1}-E_{2}\right|+\left|E_{2}-E_{3}\right|+\left|E_{3}-E_{4}\right|+\cdots+\left|E_{n-1}-E_{n}\right|$

Equation (9) presents accumulated creep strain energy density, $E_{A}$, as the sum of the absolute difference between the maximum creep strain energy density value in a cycle and the successive cycle. $\mathrm{n}$ is the number of cycle.

Equation (11), which forms part of the Engineering Data Input to ANSYS finite element environment, presents the temperature dependence of Young's Modulus of solder (Schubert et al., 2001; Wiese et al., 2001). 
Where $\mathrm{Y}$ is the Young's Modulus and $\mathrm{T}$ is the absolute temperature.

EVA material, known for its unique thermo-viscoelastic rheological properties, has been used as the encapsulation layer for PV modules providing stiffness and flexibility depending on application conditions (Eitner et al., 2010; Jamshidi et al., 2015). EVA is the most commonly used material for PV encapsulation because of relative low cost, high light transmittance, and good thermal conductivity (Agroui and Collins, 2014, 2013; Yuwawech et al., 2015). However, the degradation of the EVA layer in PV modules under non-STC conditions has been reported as discoloration, debonding and delamination (Gagliardi et al., 2017; Matsunaga et al., 2011; Rajput et al., 2017; Sinha et al., 2016). Paggi and Sapora, (2015), proposed an accurate thermo-viscoelastic rheological model for EVA based on fractional calculus. They described the viscoelasticity of EVA using power law behaviour by applying fractional dashpot model (i.e. spring pot) instead of the spring and dashpot models in the Prony series. Their results indicate EVA's constitutive behaviour significantly influences the stress and deformation of PV silicon cells, responsible for the non-linear variation in cell gap which leads to solder interconnection failure and its degradation has been attributed to electrical power output loss.

Paggi et al., (2011) in their study of the thermomechanical deformations in photovoltaic laminates, demonstrated the strong temperature-dependant behaviour of the EVA layer. They produced a chart of the relationship between Young's Modulus (E) of EVA and temperature which is presented in Fig. 3. Values of Young's Modulus of EVA at corresponding temperatures points on the thermal cycle load as shown in Fig. 2, are derived from the chart in Fig. 3, and form part of the Engineering Data input for the ANSYS finite element modelling. At each non-STC load condition, the FEM solver calls for the data as required. Modelling EVA as temperature dependent instead of linear elastic, FEM results demonstrated close results with experimental values (Eitner et al., 2011; Paggi et al., 2011). In previous research on the viscoelastic behaviour of EVA, the model of PV module utilised have comprised of glass, EVA, silicon cell and back sheet. In our present study, our model of PV module includes all the component layers: glass, EVA encapsulant, copper ribbon interconnect, solder, silver front contact, crystalline silicon wafer, aluminium back contact and Tedlar back sheet. We shall place emphasis on considering the influence that the constitutive viscoelastic behaviour of EVA has on the PV solder interconnection. 


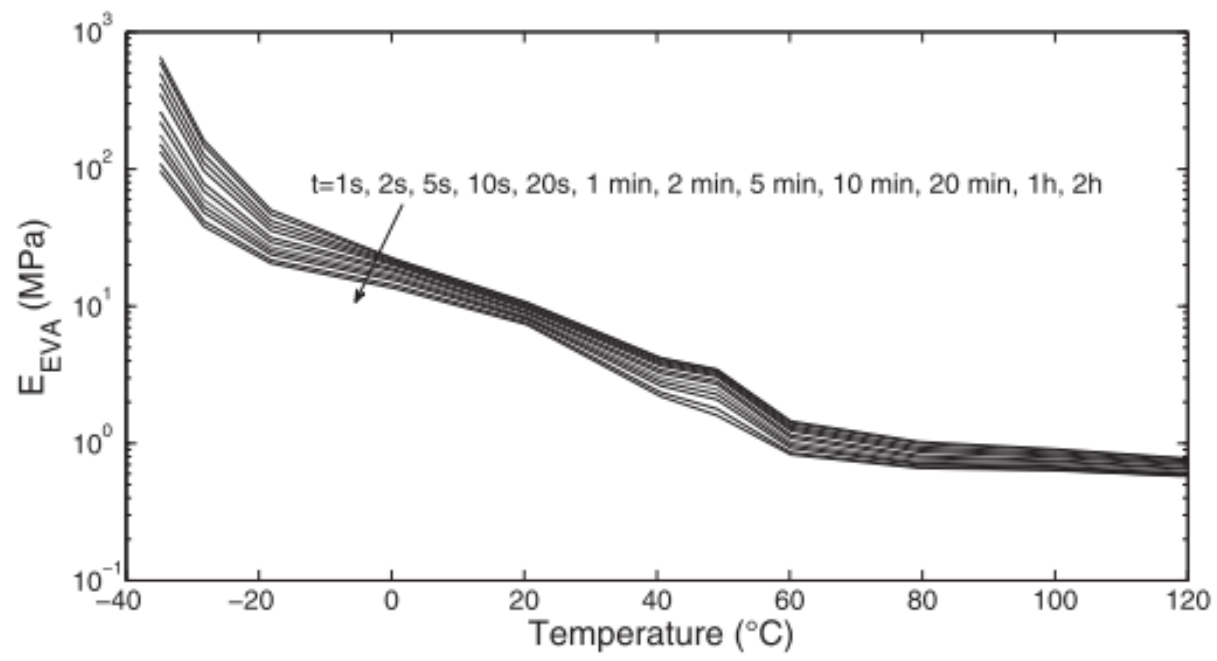

Fig. 3: Young's modulus (MPa) of EVA versus temperature $\left({ }^{\circ} \mathrm{C}\right)$, for different relaxation times (Paggi et al., 2011)

(a)

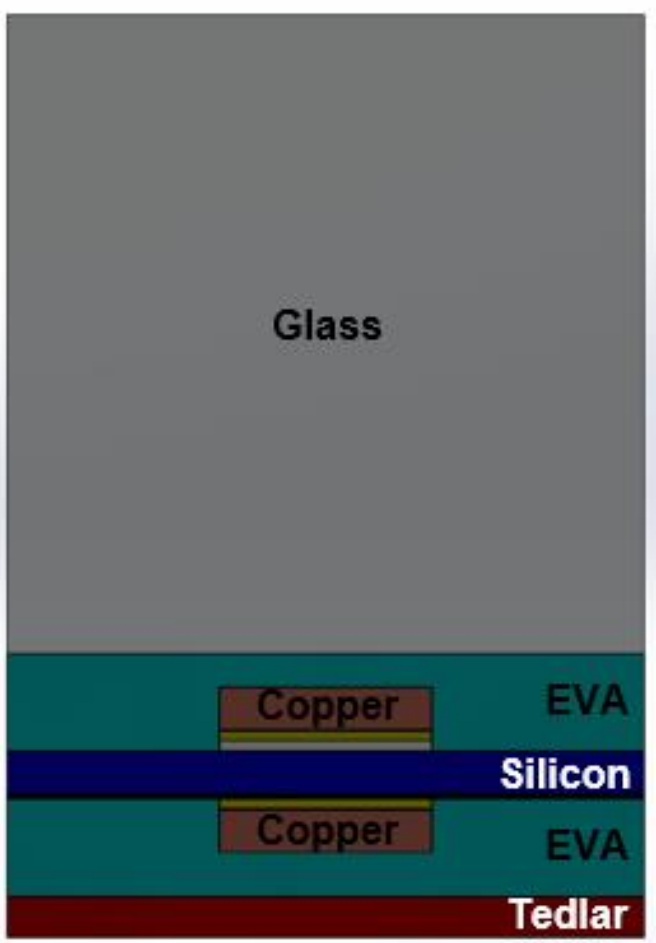

(b)

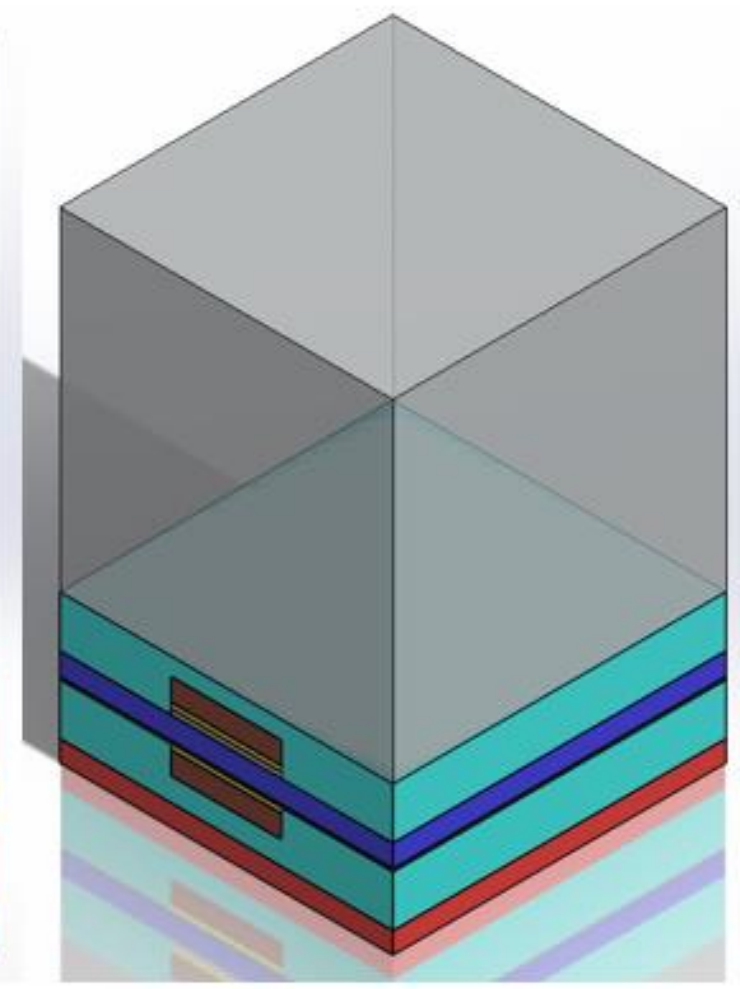

Fig. 4: PV Module Architecture end view (a) 3D view (b) 
Table 1: PV Module Component Materials and respective properties (Smith and Madeni, 2002)

\begin{tabular}{llllll}
\hline Material & $\begin{array}{l}\text { CTE } \\
\left(10^{\left.-6 / \mathrm{K}^{-1}\right)}\right.\end{array}$ & $\begin{array}{l}\text { Young's } \\
\text { Modulus } \\
(\mathrm{GPa})\end{array}$ & $\begin{array}{l}\text { Poisson } \\
\text { Ratio }\end{array}$ & $\begin{array}{l}\text { Thermal } \\
\text { conductivity } \\
(\mathrm{W} / \mathrm{mK})\end{array}$ & $\begin{array}{l}\text { Shear } \\
\text { Modulus } \\
(\mathrm{GPa})\end{array}$ \\
\hline Silver & 10.4 & 7 & 0.37 & 429 & 30.29 \\
Copper & 17 & 85.7 & 0.34 & 399 & 48.1 \\
Solder (Sn3.5Ag0.5Cu) & 23.2 & See Eqn.11 & 0.30 & 60 & See Eqn.11 \\
Aluminium & 11.9 & 6 & 0.33 & 237 & 2.2556 \\
Silicon & 3.5 & 130 & 0.22 & 148 & 53.279 \\
Glass & 8.5 & 73.3 & 0.21 & 1.8 & 30.289 \\
EVA & 270 & See Fig. 3 & 0.4999 & 0.35 & See Fig. 3 \\
Tedlar & 30 & 1.4 & 0.4 & 0.2 & 0.5 \\
Intermetallic compound & & & & & 50.21 \\
(IMC) & 16.3 & 85.56 & 0.309 & 34.1 & \\
\hline
\end{tabular}

Table 2: PV module components dimensions (Hren, 2011; SEAl, 2014)

\begin{tabular}{ll}
\hline Component & Height $(\mu \mathrm{m})$ \\
\hline Silver Front contact & 50 \\
Copper Ribbon & 200 \\
Solder (Sn3.5Ag0.5Cu) & 46 \\
Aluminium Back Contact & 25 \\
Silicon Wafer & 200 \\
Glass & 3000 \\
EVA Encapsulant & 460 \\
Tedlar Back Sheet & 190 \\
Intermetallic compound (IMC) & 5 \\
\hline
\end{tabular}

Table 3: Garofalo creep parameter values for SnAgCu solder (Dudek et al., 2003)

\begin{tabular}{lllll}
\hline Parameter & $\mathrm{C}_{1}\left(\mathrm{~s}^{-1}\right)$ & $\mathrm{C}_{2}(\mathrm{MPa})^{-1}$ & $\mathrm{C}_{3}$ & $\mathrm{C}_{4}(\mathrm{~K})$ \\
\hline Value & 277984 & 0.02447 & 6.41 & 6500 \\
\hline
\end{tabular}




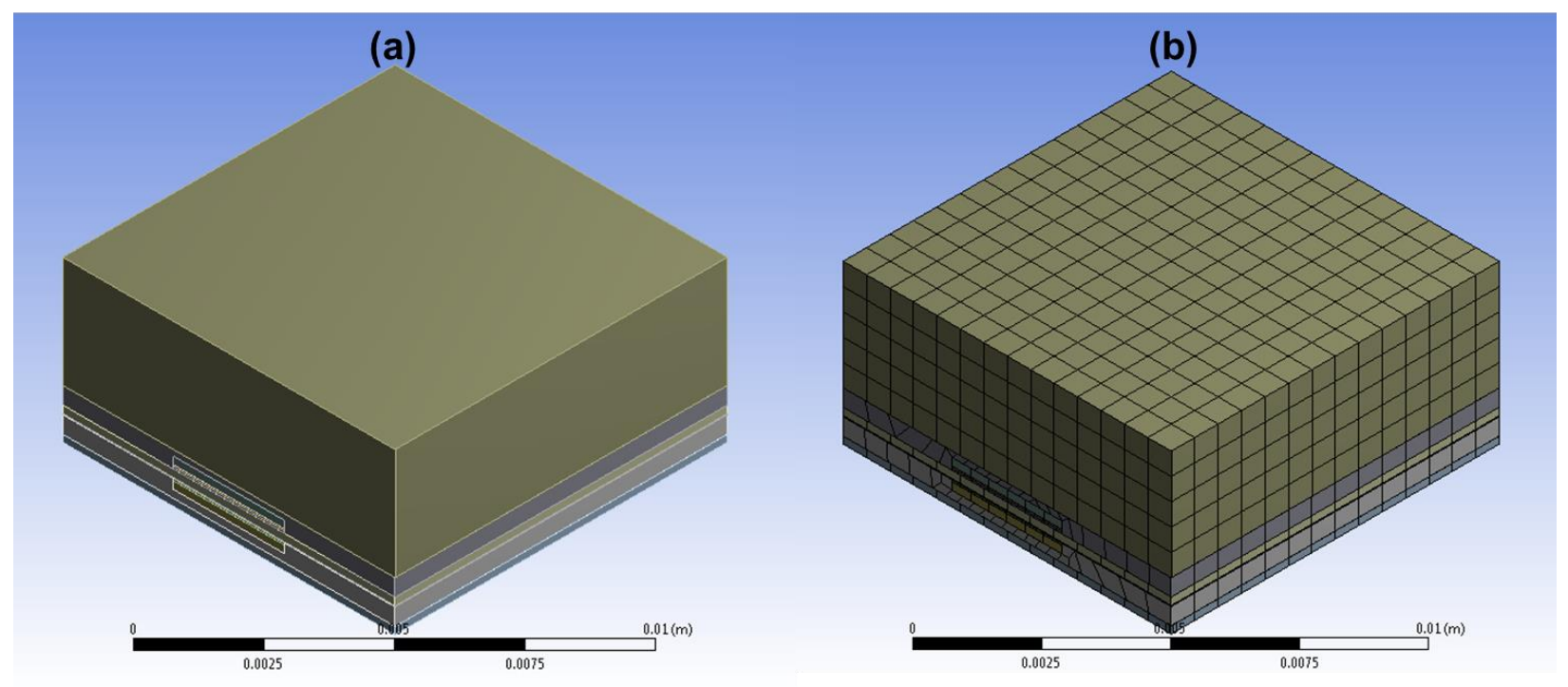

Fig. 5: PV module 3D view (a) showing mesh (b)

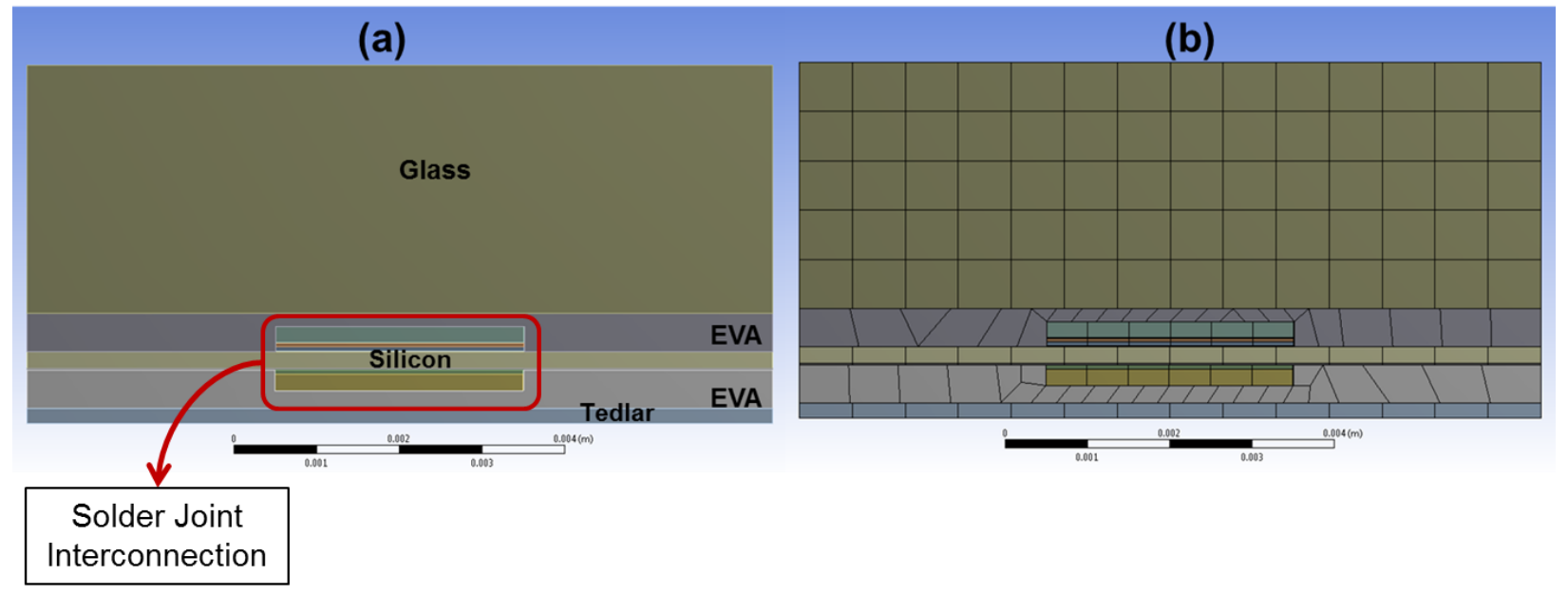

Fig. 6: PV module end view (a) showing mesh (b) 


\section{Results and discussion}

The effect of C-Si PV module operation outside the STCs, and the magnitude of operating temperatures (cell and ambient) on the degradation of PV solder interconnections are investigated using ANSYS FEM. This section presents results of the investigation. Section 4.1 discusses the solder joint degradation due to the PV cell temperature step rise from STC. Section 4.2 discusses solder joint degradation under various ambient temperatures while corresponding fatigue lives are predicted.

\subsection{Solder joint degradation under PV cell temperature rise range of $25^{\circ} \mathrm{C} \leq \mathrm{T} \leq 120^{\circ} \mathrm{C}$}

Solder joint degradation is determined at every $1^{\circ} \mathrm{C}$ temperature rise from $25^{\circ} \mathrm{C} \mathrm{STC}$. At each temperature load step, the creep strain energy is generated from the ANSYS FEM. Equation (8) is employed to derive the values for creep strain energy density. Figure 7 shows the creep strain energy distribution on solder in the ANSYS environment. The coloured key on the left-hand side of the figure indicates the graduation of damage with red as greatest and royal blue as least.

It is observed that for each $1^{\circ} \mathrm{C}$ rise in $\mathrm{PV}$ cell temperature, there is a corresponding increase in the maximum creep strain energy density. The positive correlation between the parameters is presented in Fig. 8. Figure 8 presents the plot of maximum creep strain energy density $(\mathrm{Pa})$ against $\mathrm{PV}$ cell temperatures. Three damage regions signifying three distinct PV cell temperature ranges can be seen. These discrete regional parameters are evident in the change of shape of the plot as it progresses from Region 1 through to Region 3. In Region $1\left(25\right.$ to $42^{\circ} \mathrm{C}$ ), the relationship between solder degradation and PV cell temperature is quadratic, and solder degradation rate increased from 1.53 to 10.03 $\mathrm{Pa} /{ }^{\circ} \mathrm{C}$. Region $2\left(43\right.$ to $63^{\circ} \mathrm{C}$ ) is the critical region because the solder degradation rate is highest and constant at $12.06 \mathrm{~Pa} /{ }^{\circ} \mathrm{C}$. Thus, a linear relationship between solder degradation and PV cell temperature is observed. Solder degradation rate in Region 3 $\left(64\right.$ to $120^{\circ} \mathrm{C}$ ) decreases from 5.47 to $2.25 \mathrm{~Pa} /{ }^{\circ} \mathrm{C}$, and the relationship between solder degradation and PV cell temperature is logarithmic. The decrease in damage within this range may be explained from stress relaxation point of view. Amalu and Ekere (2012) reported on the increase in ambient temperatures of solder increasing solder homologous temperatures and thus decreases its hardness. Decrease in solder hardness decreases its accumulated creep strain energy density.

The critical region, with the highest solder degradation rate, has been established as Region 2. It is of utmost importance to understand the behaviour of PV modules operating with cell temperatures in Region 2 to improve their fatigue life and reliability. This is because the range constitutes the hot climate ambient temperatures. Thus, the temperatures from region 2 are the range used in the ambient temperature experiment discussed in section 4.2 . 


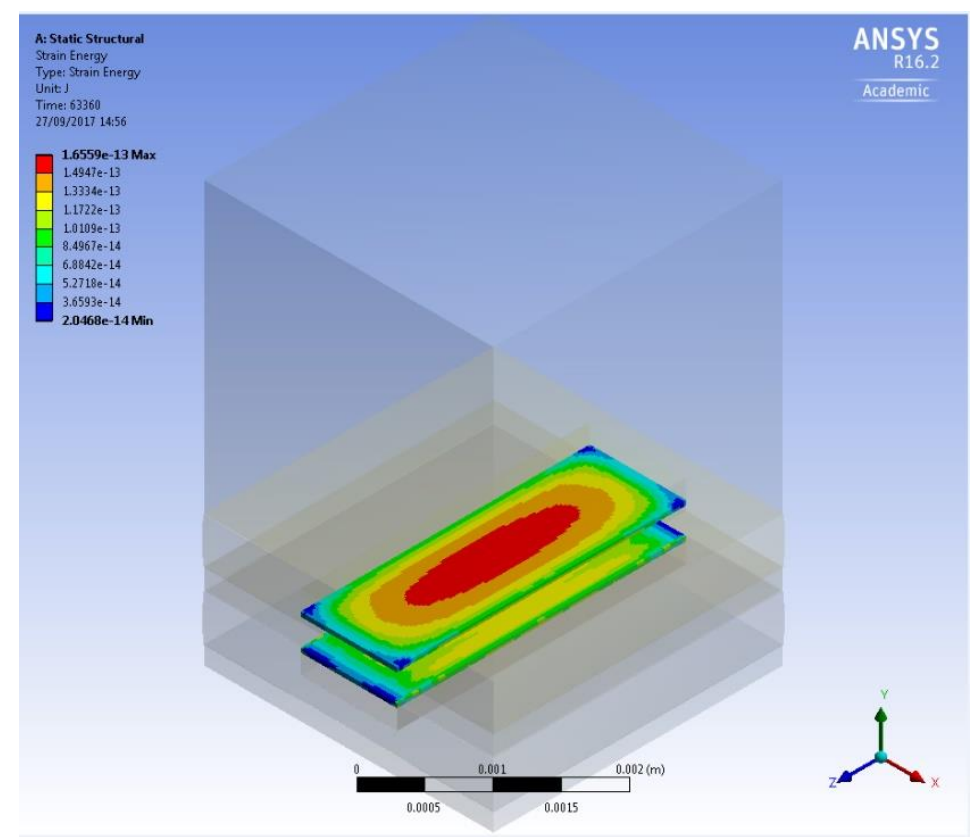

Fig. 7: Creep strain energy (solder damage) in ANSYS FEM environment

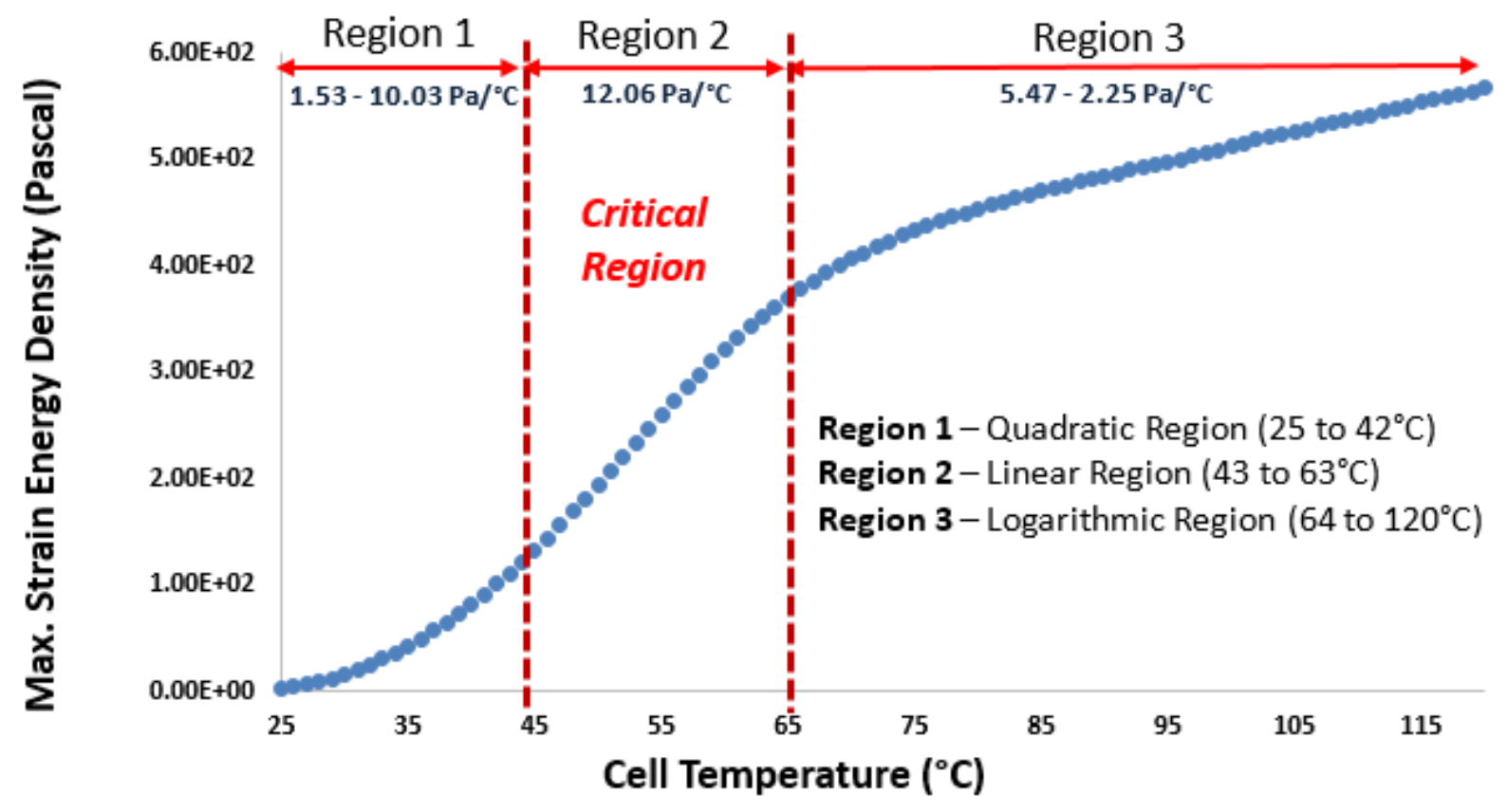

Fig. 8: Max. strain energy density against cell temperature showing three damage regions 


\subsection{Fatigue life prediction at ambient temperature range of $25^{\circ} \mathrm{C} \leq \mathrm{T}$ $\leq 45^{\circ} \mathrm{C}$}

The degradation of solder joints at ambient temperatures is investigated and quantified using the solder joint fatigue life. The temperature difference between the ambient and solar cells can be as high as $22^{\circ} \mathrm{C}$ (Kurnik et al., 2011). Equation (12) presents the relation between these two parameters.

$T_{\text {cell }} \approx T_{\text {ambient }}+22^{\circ} \mathrm{C}$

Ambient temperatures between $25^{\circ} \mathrm{C}$ and $45^{\circ} \mathrm{C}$ are used for the investigation. They are used also to generate a model that predicts the fatigue life of c-Si PV module outside this range. The region is used because the temperatures fall into the Critical Region 2. This has been described in detail in section 4.1 and seen in Fig. 8. Applying Eq. 7, the fatigue lives (cycles) at the various ambient temperatures are predicted.

$L=\left(\frac{t_{c}}{y}\right) N_{f}$

Equation (13) presents the relation between mean fatigue life, $L$ (in years) and mean fatigue life, $N_{f}$ (in cycles). $t_{c}$ is the time per cycle (in seconds), and $y$ is one year (in seconds). It is important to convert fatigue life from cycles to years so that the values can be easily understood and used in real life operations by actual consumers. Thus, Eq. (13) yields the lifetime of C-Si PV module in years.

Figure 9 is a plot of ambient temperature $\left({ }^{\circ} \mathrm{C}\right)$ and mean fatigue life (years). Fatigue life is observed to decay according to a power function. The power function in Eq. (14) is used to describe the relationship between the fatigue life and corresponding ambient temperatures.

$L=721.48 T^{-1.343}$

Where: $L$ is the Mean Fatigue Life (in years) and $T$ is the Ambient Temperature $\left({ }^{\circ} \mathrm{C}\right)$. The function provides a projection of mean fatigue life with a correlation coefficient of 0.9025 . The power function curve is plotted alongside the curve for the measured values of mean fatigue life from FEM.

Equation (14) is a handy relation that can easily be applied by consumers to predict the lifespan of a c-Si PV module operating in their region.

Table 4 displays the accumulated creep strain energy density and fatigue lives at respective ambient temperatures. Equations (9) and (10) are employed to calculate the accumulated creep strain energy density under each corresponding ambient temperature load condition. The lowest solder damage of $0.01203 \mathrm{~Pa}$ was recorded at $25^{\circ} \mathrm{C}$ while the highest damage of $0.05207 \mathrm{~Pa}$ was at $45^{\circ} \mathrm{C}$. The fatigue life, the longest of 59355 cycles 
to failure (9.6 years) was recorded at $25^{\circ} \mathrm{C}$ while at $45^{\circ} \mathrm{C}$, the shortest of 13718 cycles to failure (4.3 years) was recorded. Figure 10 presents the variation of Mean Fatigue Life with Ambient Temperature. Figure 11 is a plot of equivalent stress $(\mathrm{Pa})$ against equivalent strain; also known as hysteresis loops, at ambient temperatures $25^{\circ} \mathrm{C}$ and $45^{\circ} \mathrm{C}$. The area under the loops represents the creep strain energy dissipated and accumulated in the PV solder joints. The larger area and hence the greatest solder joint degradation is observed at $45{ }^{\circ} \mathrm{C}$. This is in agreement with research on the relationship between hysteresis loop size and temperature (Mustafa et al., 2011)(Vandevelde et al., 2007).

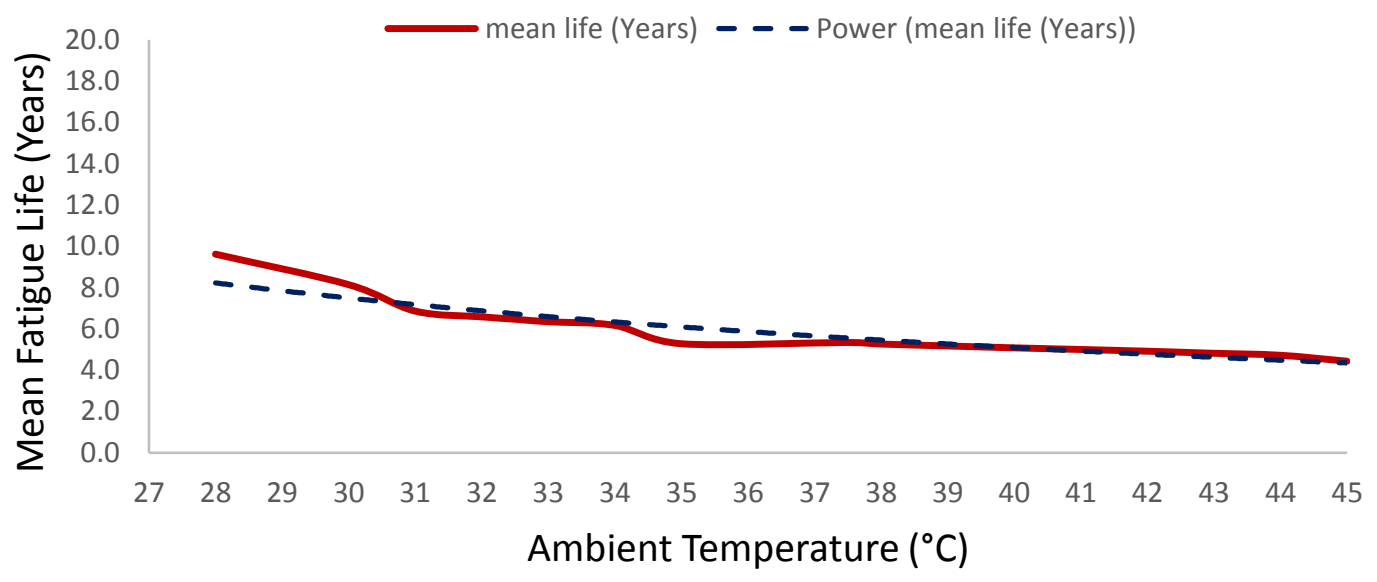

Fig. 9: Plot of mean fatigue life (Years) against ambient temperatures $\left({ }^{\circ} \mathrm{C}\right)$. 
Table 4: Solder joint degradation and mean fatigue lives at corresponding ambient temperatures

\begin{tabular}{|c|c|c|c|}
\hline $\begin{array}{l}\text { Ambient } \\
\text { Temperature } \\
\left({ }^{\circ} \mathrm{C}\right)\end{array}$ & $\begin{array}{l}\text { Accumulated Max. } \\
\text { Strain Energy } \\
\text { Density }\left(10^{-2} \mathrm{~Pa}\right)\end{array}$ & $\begin{array}{l}\text { Mean fatigue } \\
\text { life } \\
\text { (104cycles) }\end{array}$ & $\begin{array}{l}\text { Mean fatigue } \\
\text { life (Years) }\end{array}$ \\
\hline 25 & 1.20 & 5.93 & 9.6 \\
\hline 27.5 & 2.23 & 3.20 & 8.4 \\
\hline 30 & 2.84 & 2.52 & 7.5 \\
\hline 32.5 & 3.57 & 2.00 & 6.7 \\
\hline 35 & 4.37 & 1.63 & 6.1 \\
\hline 37.5 & 4.32 & 1.65 & 5.6 \\
\hline 40 & 4.54 & 1.57 & 5.1 \\
\hline 42.5 & 4.74 & 1.51 & 4.7 \\
\hline 45 & 5.21 & 1.37 & 4.3 \\
\hline
\end{tabular}

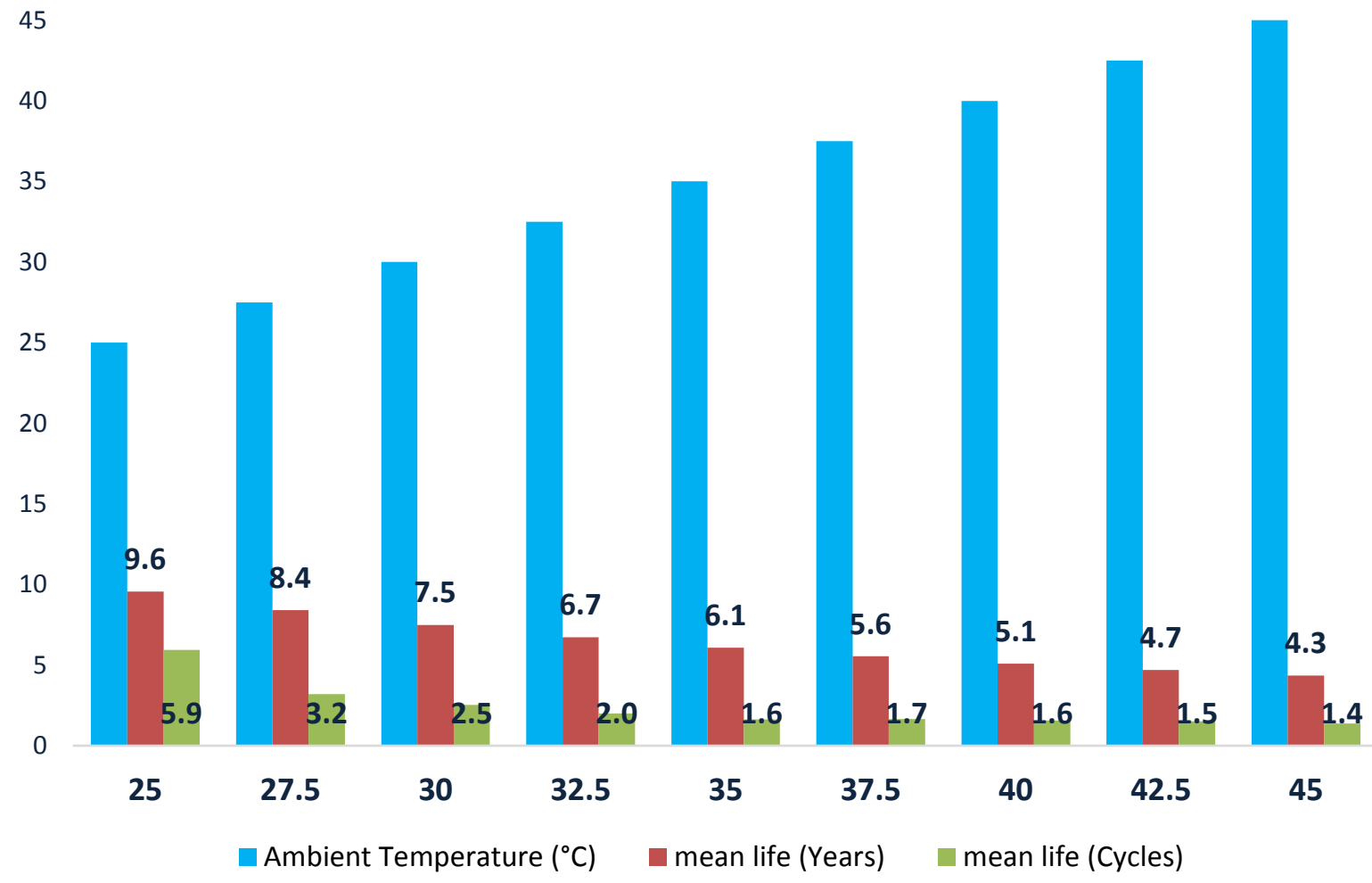

Fig. 10: Mean Fatigue Life variation with Ambient Temperature $\left({ }^{\circ} \mathrm{C}\right)$ 


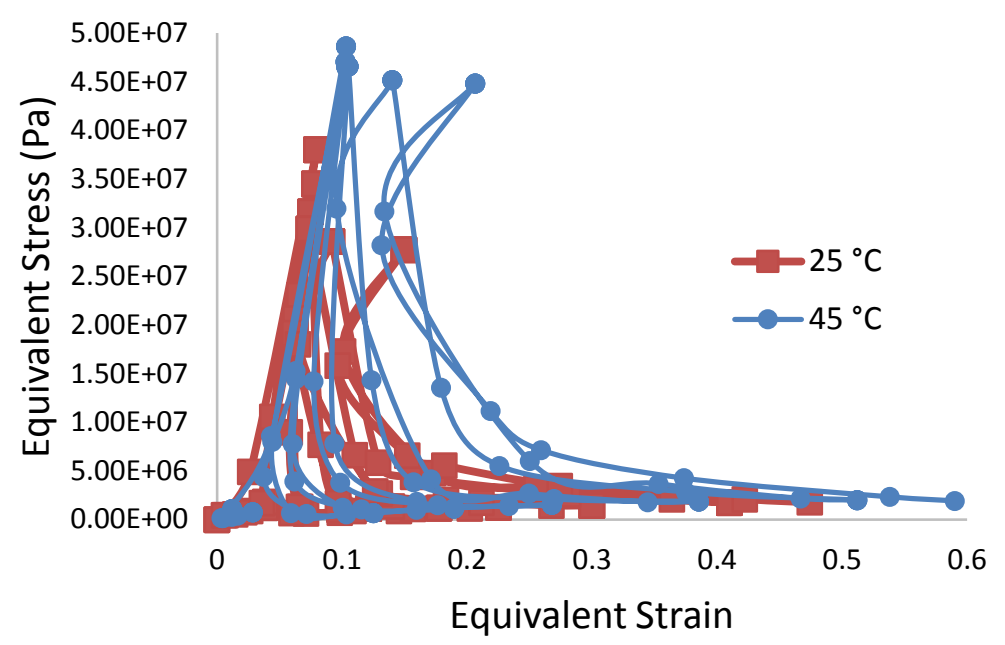

Fig. 11: Equivalent stress (Pa) versus equivalent strain at ambient temperatures $25^{\circ} \mathrm{C}$ and $45^{\circ} \mathrm{C}$

\subsection{Effect of cycle number on determination of accurate degradation of solder joint in PV module}

Figure 12 is the plot of equivalent stress $(\mathrm{Pa})$ over cycle number at various ambient temperatures. The plot demonstrates highest equivalent stress magnitudes at $25^{\circ} \mathrm{C}$ and lowest at $45^{\circ} \mathrm{C}$ in the first cycle. A transition domain can be observed from the end of cycle one to the the end of cycle four with a turning point at cycle three. At cycle three, all the stress curves converge at a magnitude. Subsequently, cycling shows the curve diverge with $45^{\circ} \mathrm{C}$ being the highest and the $25^{\circ} \mathrm{C}$ the lowest at the end of cycle four. The trend continues for the rest of the thermal cycles. The observation is in line with reports by (Amalu and Ekere, 2016; Zhang et al., 2003) that equivalent stress values are highest from cycle 3 onwards and at least six thermal cycles are sufficent to qualify solder joint degradation (Amalu and Ekere (2012b).

Figure 13 is the plot of equivalent strain over cycle time at various ambient temperatures. The strain curves show little disparity until cycle 3 where there is divergence which is sustained throughout the remainder of the cycle load. In addition, Figs. 14a and 14b show the equivalent stress and equivalent strain distribution respectively in the ANSYS FEM environment at $45^{\circ} \mathrm{C}$. The coloured key shows the graduation with red as highest and royal blue as lowest.

This behaviour of the solder can be partly attributed to the nature of the IEC 61215 test standard thermal load. The thermal load with the slow ramp rate of $1.667^{\circ} \mathrm{C} / \mathrm{min}$ causes the stress to be accumulated in the joint gradually. In such a case thermal shock is minimal. It is noteworthy therefore, that accelerated thermal cycling (ATC) in FEM should not be carried out with cycle number less than 3 . Otherwise results may be misleading. The claim can be observed in Fig. 12 where before cycle 3, the maximum stress values were at the lowest ambient temperature of $25^{\circ} \mathrm{C}$ and the minimum stress values at the 
highest ambient of $45^{\circ} \mathrm{C}$. However, after cycle 3, the expected trend is observed with the maximum stress values at the highest ambient temperature of $45^{\circ} \mathrm{C}$.

Another contributor to the behaviour of solder is that it was modelled using the temperature dependent model in Eq. (11). Also, EVA encapsulant which has been reported to influence the behaviour of the solder interconnection has been modelled as viscoelastic as opposed to linear elastic which means results tally with those from laboratory experiments. Figure 3 shows the plot of Young's Modulus of EVA against temperature.

The experimental characterisation of material degradation as a result of cyclic deformation has been studied by several researchers (Borri et al., 2018; Paggi et al., 2014, 2013; Phinikarides et al., 2014). Borri et al., (2018), in their study on the fatigue crack growth in silicon solar cells and hysteretic behaviour of busbars, focused on the plastic deformation of PV module busbars. The investigation was performed experimentally utilising cyclic bending tests, non-destructive monitoring techniques based on thermal infrared imaging and electroluminescence. Their reported responses of PV busbar include increase in strain with cycle number, widening of the region between two silicon PV cells from $2 \mathrm{~mm}$ at room temperature to up to $2 \mathrm{~mm}+60 \mu \mathrm{m}$ at the maximum field temperature of $80^{\circ} \mathrm{C}$. Our present study focused on the degradation of solder under non-STC temperature loads using finite element modelling environment. The values for temperature dependent Young's Modulus of solder derived from Eq. (11) reveal values lower than that of the copper busbar which means said deformation of solder occurs before the plastic region of copper busbar. Additionally, the stress-strain levels shown in the hysteresis loops of Fig. 11, which indicate the creep strain energy accumulated in the solder layer, are lower than those of the plastic regime of the copper busbar. However, the authours have ear-marked for future research, the experimenatal determination of solder interconnection degradation taking into account material properties interactions involving creep behaviour, plastic and cyclic deformations.

Several researches have investigated the effect of intermetallic compound (IMC) layer on solder joint reliability (Amalu et al., 2011; Amalu and Ekere, 2012a, 2012b; George, 2010; Nadimpalli and Spelt, 2011; Xiao et al., 2013). Amalu and Ekere, (2012a), in their prediction of damage and fatigue life of high-temperature flip chip assembly interconnections at operations, utillised 3D flip chip models simulated in ANSYS 13 to investgate the damage of bonded materials. They ascertained the IMC layer between solder and copper die as most vulnerable to crack initiation and propagation. In their later study (Amalu and Ekere, 2012b) on the damage of lead-free solder joints in flip chip assemblies subjected to high-temperature thermal cycling, they evalauted the effect of IMC layer thickness on solder joint reliability. They varied IMC layer thickness in the five flip chip models simulated in ANSYS and they observed that models with the thickest and thinnest IMC layers impacted the reliability of solder joints. Previous studies have been published on the effect of IMC layer on ball solder joints in PCBs and other surface mount electronics but there is none on composite solder joints in PV modules especially under 
various non-standard ambient and cell temperatures. Our present study focuses on the degradation of PV solder interconnections under non-STC loads but has left the effect of the IMC layer for future investigations. We aim to combine laboratory experiments, which include apparatus like the Scanning Electron Microscope, with finite element modelling to ascertain the influence of the IMC layer on solder and overall PV module reliability.

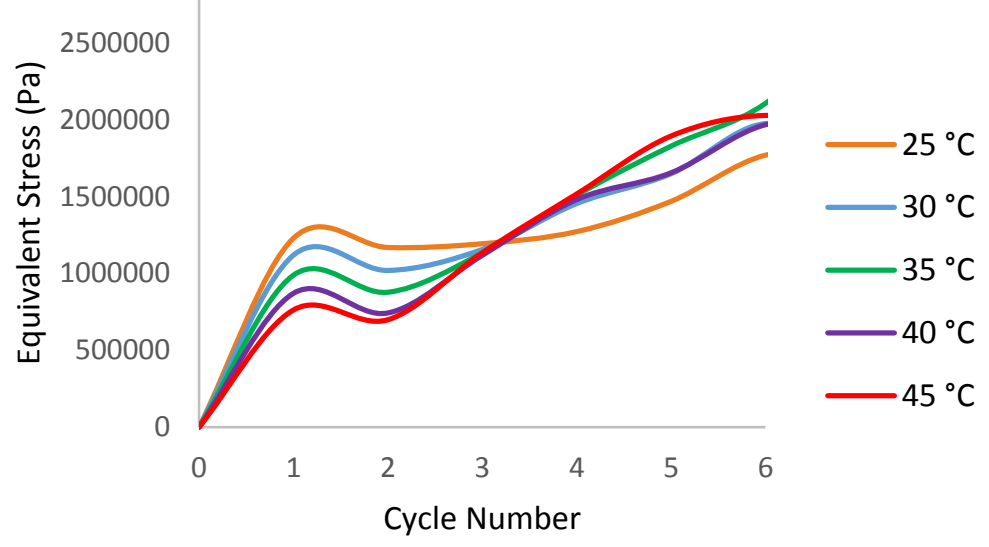

Fig. 12: Equivalent stress $(\mathrm{Pa})$ over cycle number at various ambient temperatures

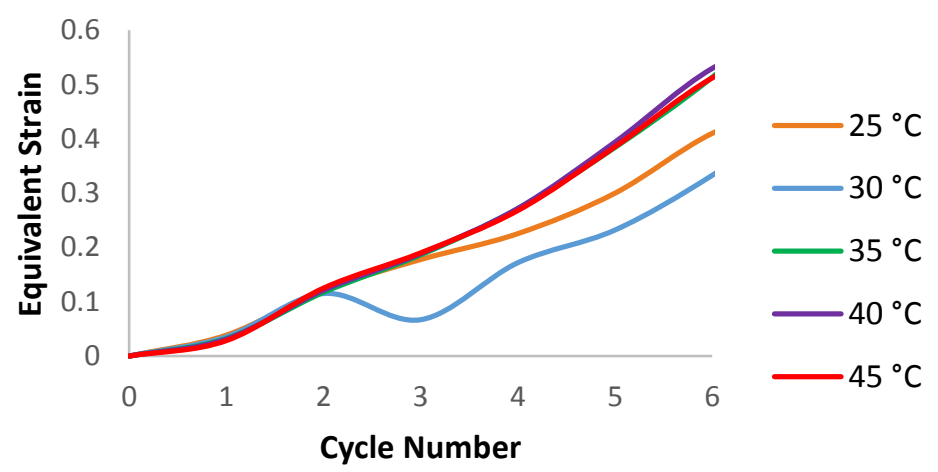

Fig. 13: Equivalent strain over cycle number at various ambient temperatures 


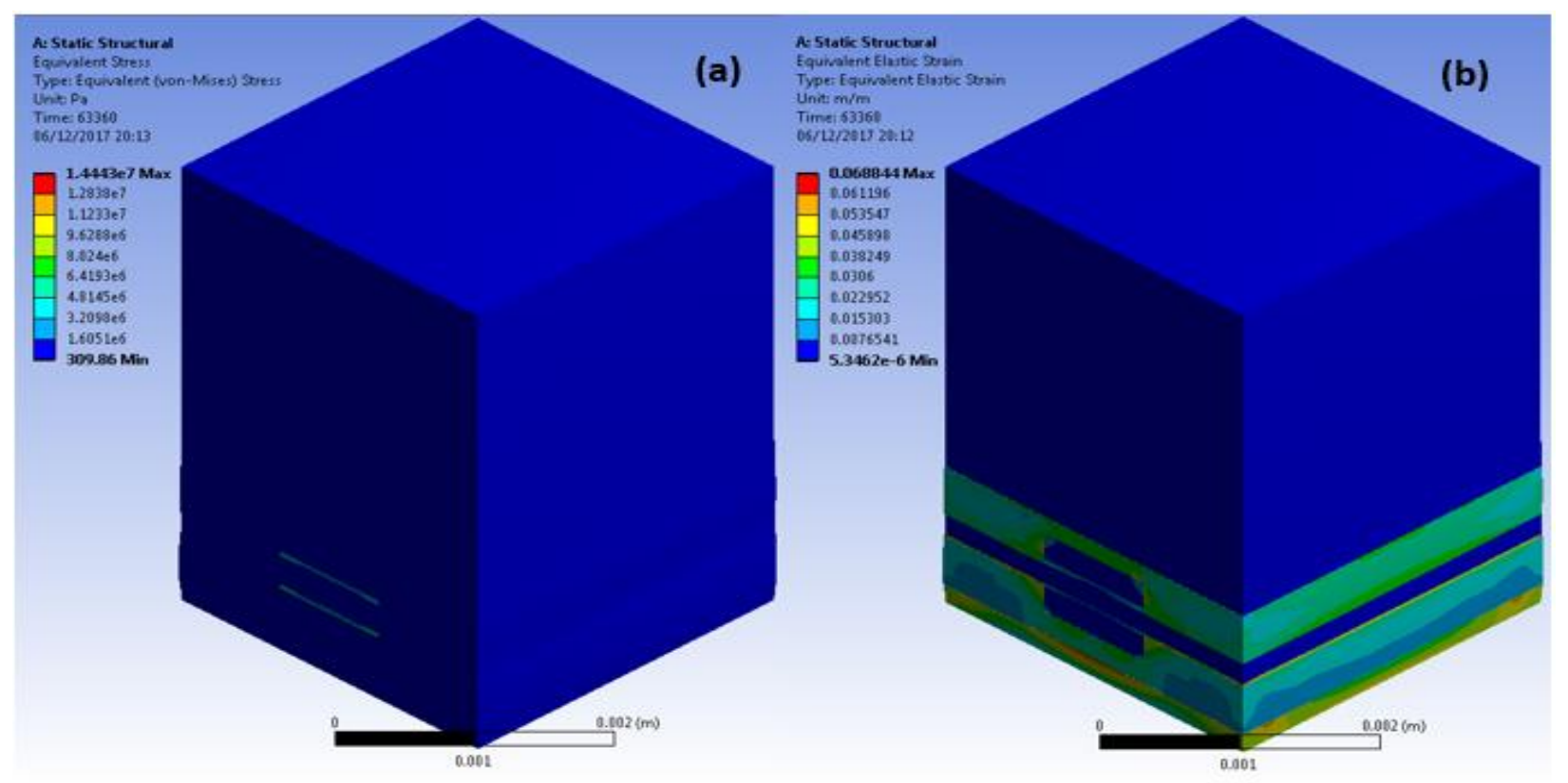

Fig. 14: Equivalent stress (a) Equivalent Strain (b) at $45^{\circ} \mathrm{C}$ ambient temperature

\section{Conclusion}

An investigation on the effect of PV cell temperature and ambient temperature on the degradation of solder joint interconnection for improved crystalline silicon PV module operation in hot climate was carried out using ANSYS FE modelling.

Based on the results and findings of the research, conclusions can be drawn. Elevated operating temperatures in excess of the $25{ }^{\circ} \mathrm{C} \mathrm{STC}$ accelerates degradation of solder joint interconnections in c-Si PV module. Operations resulting in cell temperature between $43^{\circ} \mathrm{C}$ and $63^{\circ} \mathrm{C}$ are critical and induce maximum damage in the solder joint. This range is characteristic of hot climate and explains the high failure rate of c-Si PV module observed in the region. Consequently, operation in the range should be avoided. The authors advise for incorporation a system capable of cooling the c-Si PV module operating in the region.

A model $L=721.48 T^{-1.343}$ is generated. The model demonstrates capability of quick prediction of the life of $\mathrm{c}$-Si PV module in years under different ambient temperature conditions. The model can be used by consumers for quick name plate rating. The model predicts module life in London and hot climate to be 18.5 and 9 years, respectively. The London module life is close to the 25 -year warranty within 1.4 factor of design/safety. The 9 years predicted in hot climate gives an indication of the high failure rate observed in the region.

Analyses on the degradation of PV module component layers considering the interactions between layer interfaces provides a more robust but complex investigation; and hence is the subject of future investigation. In addition, a combined research method involving laboratory experiments and finite element modelling will be utilised for more advanced 
models that consider imperfect bonding of component layer interfaces, paying particular interest to the influence of the IMC layer on solder and overall PV module reliability under non-STC load conditions. Also, experimental determination of the thermo-mechanical degradation of the PV module considering material properties interactions including viscoelasticity, plasticity and fatigue life prediction in the plastic regime.

These findings inform on the degradation of PV solder joints in different operating temperatures and advise on module operations. To ensure longevity of lifespan and attractive return on investment, the thermo-mechanical reliability and performance of crystalline silicon PV modules in hot climates requires improvement.

\section{Acknowledgement}

The authors acknowledge the Schlumberger Faculty for the Future Foundation for funding the research reported in parts in this article. The authors are grateful to the staff of the University of Wolverhampton and University of Benin, Nigeria for their support/assistance and for providing some field data on PV module operations.

\section{References}

Agroui, K., Collins, G., 2014. Determination of thermal properties of crosslinked EVA encapsulant material in outdoor exposure by TSC and DSC methods. Renew. Energy 63, 741-746. doi:10.1016/J.RENENE.2013.10.013

Agroui, K., Collins, G., 2013. Thermal relaxations and transitions in EVA encapsulant material during photovoltaic module encapsulation process. Mater. Process. Energy Commun. Curr. Res. Technol. Dev.

Amalu, E.H., Ekere, N.N., 2012a. Prediction of damage and fatigue life of hightemperature flip chip assembly interconnections at operations. Microelectron. Reliab. 52, 2731-2743. doi:10.1016/j.microrel.2012.04.004

Amalu, E.H., Ekere, N.N., 2012b. Damage of lead-free solder joints in flip chip assemblies subjected to high-temperature thermal cycling. Comput. Mater. Sci. 65, 470-484. doi:10.1016/j.commatsci.2012.08.005

Amalu, E.H., Lau, W.K., Ekere, N.N., Bhatti, R.S., Mallik, S., Otiaba, K.C., Takyi, G., 2011. A study of SnAgCu solder paste transfer efficiency and effects of optimal reflow profile on solder deposits. Microelectron. Eng. 88, 1610-1617. doi:10.1016/j.mee.2011.02.104

Arndt, R., Robert Puto, I., 2010. Basic Understanding of IEC Standard Testing For Photovoltaic Panels. TÜV SÜD Prod. Serv.

Bastidas-Rodriguez, J.D., Franco, E., Petrone, G., Ramos-Paja, C.A., Spagnuolo, G., 2017. Quantification of photovoltaic module degradation using model based indicators. Math. Comput. Simul. 131, 101-113. doi:10.1016/j.matcom.2015.04.003 
Belward, A., Bisselink, B., Bódis, K., Brink, A., Dallemand, J., Roo, A. De, Huld, T., Kayitakire, F., Mayaux, P., Ossenbrink, H., Pinedo, I., Sint, H., Thielen, J., Szabó, S., Tromboni, U., Willemen, L., Monforti, F., 2011. Renewable energies in Africa. doi:10.2788/1881

Borri, C., Gagliardi, M., Paggi, M., 2018. Fatigue crack growth in Silicon solar cells and hysteretic behaviour of busbars. Sol. Energy Mater. Sol. Cells. doi:10.1016/j.solmat.2018.02.016

Bosco, N., 2010. Reliability Concerns Associated with PV Technologies failure_references.pdf [WWW Document]. Natl. Renew. Energy Lab. URL http://www.nrel.gov/pv/performance_reliability/pdfs/failure_references.pdf (accessed 11.13.15).

Chandel, S.S., Nagaraju Naik, M., Sharma, V., Chandel, R., 2015. Degradation analysis of 28 year field exposed mono-c-Si photovoltaic modules of a direct coupled solar water pumping system in western Himalayan region of India. Renew. Energy 78, 193-202. doi:10.1016/j.renene.2015.01.015

Dubey, S., Sarvaiya, J.N., Seshadri, B., 2013. Temperature dependent photovoltaic (PV) efficiency and its effect on PV production in the world - A review. Energy Procedia 33, 311-321. doi:10.1016/j.egypro.2013.05.072

Dudek, R., Auersald, E., Gollhardt, A., Michel, B., 2003. Fatigue life models of SnAgCu and $\mathrm{SnPb}$ solder joints evaluated by experiments and simulations, in: Electronic Components and Technology Conference. pp. 603-610.

Eitner, U., Kajari-Schröder, S., Köntges, M., Brendel, R., 2010. NON-LINEAR MECHANICAL PROPERTIES OF ETHYLENE-VINYL ACETATE (EVA) AND ITS RELEVANCE TO THERMOMECHANICS OF PHOTOVOLTAIC MODULES, in: 25th European Photovoltaic Solar Energy Conference, . Valencia, Spain, pp. 1-3.

Eitner, U., Pander, M., Kajari-Schroder, S., Kontges, M., Altenbach, H., 2011. Thermomechanics of PV Modules Including the Viscoelasticity of EVA, in: 26th European Photovoltaic Solar Energy Conference and Exhibition. Hamburg, Germany, pp. 3267-3269.

Eludoyin, O.M., Adelekan, I.O., Webster, R., Eludoyin, a. O., 2014. Air temperature, relative humidity, climate regionalization and thermal comfort of Nigeria. Int. J. Climatol. 34, 2000-2018. doi:10.1002/joc.3817

Ferrara, C., Philipp, D., 2012. Why do PV modules fail? Energy Procedia 15, 379-387. doi:10.1016/j.egypro.2012.02.046

Gagliardi, M., Lenarda, P., Paggi, M., 2017. A reaction-diffusion formulation to simulate EVA polymer degradation in environmental and accelerated ageing conditions. Sol. Energy Mater. Sol. Cells 164, 93-106. doi:10.1016/j.solmat.2017.02.014

George, E., 2010. THERMAL CYCLING RELIABILITY OF LEAD- FREE SOLDERS (SAC305 AND SN3.5AG) FOR HIGH TEMPERATURE APPLICATIONS. Univ. Maryl. XXXIII, 81-87. doi:10.1007/s13398-014-0173-7.2

Gujba, H., Mulugetta, Y., Azapagic, A., 2011. Power generation scenarios for Nigeria: An environmental and cost assessment. Energy Policy 39, 968-980. 
doi:10.1016/j.enpol.2010.11.024

Harrington, R., 2015. This incredible fact will get you psyched about solar [WWW Document]. Tech News, Bus. Insid. UK. URL http://uk.businessinsider.com/this-isthe-potential-of-solar-power-2015-9? $r=U S \& I R=T$ (accessed 9.4.17).

Hren, R., 2011. Understanding PV Module Specifications [WWW Document]. Home Power Mag. URL https://www.homepower.com/articles/solar-electricity/equipmentproducts/understanding-pv-module-specifications (accessed 9.7.17).

Huld, T., Gottschalg, R., Beyer, H.G., Topič, M., 2010. Mapping the performance of PV modules, effects of module type and data averaging. Sol. Energy 84, 324-338. doi:10.1016/j.solener.2009.12.002

Hussein, H.M.S., Ahmad, G.E., El-Ghetany, H.H., 2004. Performance evaluation of photovoltaic modules at different tilt angles and orientations. Energy Convers. Manag. 45, 2441-2452. doi:10.1016/j.enconman.2003.11.013

Ike, C.., 2013. The Effect of Temperature on the Performance of A Photovoltaic Solar System In Eastern Nigeria. Res. Inven. Int. J. Eng. Sci. 3, 10-14.

Jamshidi, Y.T., Sadeghnejad, S., Sadighi, M., 2015. Viscoelastic Behavior Determination of EVA Elastomeric Foams using FEA, in: $23 \mathrm{Rd}$ Annual International Conference on Mechanical Engineering-ISME. Tehran, Iran.

Jeong, J.-S., Park, N., Han, C., 2012. Field failure mechanism study of solder interconnection for crystalline silicon photovoltaic module. Microelectron. Reliab. 52, 2326-2330. doi:10.1016/j.microrel.2012.06.027

Jordan, D.C., Kurtz, S.R., 2013. Photovoltaic degradation rates - An Analytical Review. Prog. Photovoltaics Res. Appl. doi:10.1002/pip.1182

Jordan, D.C., Silverman, T.J., Wohlgemuth, J.H., Kurtz, S.R., VanSant, K.T., 2017. Photovoltaic failure and degradation modes. Prog. Photovoltaics Res. Appl. 25, 318-326. doi:10.1002/pip.2866

Jordan, D.C., Smith, R.M., Osterwald, C.R., Gelak, E., Kurtz, S.R., 2010. Outdoor PV degradation comparison, in: Conference Record of the IEEE Photovoltaic Specialists Conference. doi:10.1109/PVSC.2010.5616925

Kato, K., 2012. PV module failures observed in the field - solder bond and bypass diode failures -. Int. Energy Agency.

King, D.L., Boyson, W.E., Kratochvil, J.A., 2002. Analysis of Factors Influencing the Annual Energy Production of Photovoltaic Systems, in: Photovoltaic Specialists Conference, Conference Record of the 29th IEEE. pp. 1356-1361.

Köntges, M., Kurtz, S., Packard, C., Jahn, U., Berger, K., Kato, K., Friesen, T., Liu, H., Van Isehegam, M., 2014. review_of_failures_of_pv_modules_final.pdf [WWW Document]. Inst. Sol. Energy Res. Hamelin, Emmerthal, Ger. URL http://www.isfh.de/institut_solarforschung/files/iea_t13_review_of_failures_of_pv_m odules_final.pdf (accessed 11.13.15).

Kurnik, J., Jankovec, M., Brecl, K., Topic, M., 2011. Outdoor testing of PV module temperature and performance under different mounting and operational conditions. 
Sol. Energy Mater. Sol. Cells 95, 373-376. doi:10.1016/j.solmat.2010.04.022

Lenarda, P., Paggi, · M, 2016. A geometrical multi-scale numerical method for coupled hygro-thermo-mechanical problems in photovoltaic laminates. Comput. Mech. 57, 947-963. doi:10.1007/s00466-016-1271-5

Ltd), A.K.P. (lota T., 2011. ReliabilityChallengesforSolarModules.pdf [WWW Document]. URL

http://www.asmeconferences.org/InterPACK2011/pdfs/ReliabilityChallengesforSola rModules.pdf (accessed 11.13.15).

Maehlum, M.A., 2013. What is the Potential of Solar Energy? [WWW Document]. Energy Inf. URL http://energyinformative.org/potential-of-solar-energy/ (accessed 9.4.17).

Matsunaga, S., Aoyagi, T., Kuramitsu, M., Yamamoto, E., Ogawa, S., 2011. Viscoelastic Study of PV Module Encapsulant for the Prediction of Thermal Durability, in: 26th European Photovoltaic Solar Energy Conference and Exhibition. Hamburg, Germany, pp. 3295-3297.

Menka, A., Chris, J., Laniera, O., Simpsonc, R., Stephane, P., 2011. Lifetime Prediction for Solder Joints with the Extended Finite Element Method Mesh generation for a grain structure ( grain boundaries are indicated by blue lines ). Semi-Therm 1-8.

Mi, J., Li, Y.-F., Yang, Y.-J., Peng, W., Huang, H.-Z., 2014. Thermal Cycling Life Prediction of Sn-3.0Ag-0.5Cu Solder Joint Using Type-I Censored Data. Sci. World.

Munoz, M.A., Alonso-Garcia, M.C., Vela, N., Chenlo, F., 2011. Early degradation of silicon PV modules and guaranty conditions. Sol. Energy 85, 2264-2274. doi:10.1016/j.solener.2011.06.011

Mustafa, M., Cai, Z., Suhling, J.C., Lall, P., 2011. The effects of aging on the cyclic stress-strain behavior and hysteresis loop evolution of lead free solders, in: 61st Electronic Components and Technology Conference. pp. 927-939.

Nadimpalli, S.P.V., Spelt, J.K., 2011. Effect of geometry on the fracture behavior of lead-free solder joints. Eng. Fract. Mech. 78, 1169-1181. doi:10.1016/j.engfracmech.2011.01.026

Ndiaye, A., Charki, A., Kobi, A., Kébé, C.M.F., Ndiaye, P.A., Sambou, V., 2013. Degradations of silicon photovoltaic modules: A literature review. Sol. Energy 96, 140-151. doi:10.1016/j.solener.2013.07.005

Ndiaye, A., Kébé, C.M.F., Charki, A., Ndiaye, P.A., Sambou, V., Kobi, A., 2014. Degradation evaluation of crystalline-silicon photovoltaic modules after a few operation years in a tropical environment. Sol. Energy 103, 70-77. doi:10.1016/j.solener.2014.02.006

Obinata, K., Kato, N., Takeda, Y., Motohiro, T., 2010. Geometrical Optimization of Arrangement of Solar Cells in Photovoltaic Modules. Forma 31-35.

Ogbomo, O.O., Amalu, E.H., Ekere, N.N., Olagbegi, P.O., 2017. A review of photovoltaic module technologies for increased performance in tropical climate. Renew. Sustain. Energy Rev. 75, 1225-1238. doi:10.1016/j.rser.2016.11.109 
Ojo, S.O., Paggi, M., 2016a. A 3D coupled thermo-visco-elastic shear-lag formulation for the prediction of residual stresses in photovoltaic modules after lamination. Compos. Struct. 348-359. doi:10.1016/j.compstruct.2016.08.036

Ojo, S.O., Paggi, M., 2016b. A thermo-visco-elastic shear-lag model for the prediction of residual stresses in photovoltaic modules after lamination. Compos. Struct. 481492. doi:10.1016/j.compstruct.2015.10.023

Pacca, S., Sivaraman, D., Keoleian, G. a., 2007. Parameters affecting the life cycle performance of PV technologies and systems. Energy Policy 35, 3316-3326. doi:10.1016/j.enpol.2006.10.003

Paggi, M., Berardone, I., Infuso, A., Corrado, M., 2014. Fatigue degradation and electric recovery in Silicon solar cells embedded in photovoltaic modules. Sci. Rep. 4506. doi:10.1038/srep04506

Paggi, M., Corrado, M., Rodriguez, M.A., 2013. A multi-physics and multi-scale numerical approach to microcracking and power-loss in photovoltaic modules. Compos. Struct. 630-638. doi:10.1016/j.compstruct.2012.08.014

Paggi, M., Kajari-Schröder, S., Eitner, U., 2011. Thermomechanical deformations in photovoltaic laminates. J. Strain Anal. Eng. Des. 46, 772-782. doi:10.1177/0309324711421722

Paggi, M., Sapora, A., 2015. An Accurate Thermoviscoelastic Rheological Model for Ethylene Vinyl Acetate Based on Fractional Calculus. Int. J. Photoenergy 2015, 17. doi: $10.1155 / 2015 / 252740$

Phinikarides, A., Kindyni, N., Makrides, G., Georghiou, G.E., 2014. Review of photovoltaic degradation rate methodologies. Renew. Sustain. Energy Rev. 143152. doi:10.1016/j.rser.2014.07.155

Rajput, P., Sastry, O.S., Tiwari, G.N., 2017. Effect of irradiance, temperature exposure and an Arrhenius approach to estimating weathering acceleration factor of Glass, EVA and Tedlar in a composite climate of India. Sol. Energy 144, 267-277. doi:10.1016/j.solener.2017.01.027

Sander, M., Henke, B., Schweizer, S., Ebert, M., Bagdahn, J., 2010. PV module defect detection by combination of mechanical and electrical analysis methods, in: 35th IEEE Photovoltaic Specialists Conference. IEEE, pp. 001765-001769. doi:10.1109/PVSC.2010.5615878

Schubert, A., Walter, H., Dudek, R., Michel, B., Lefranc, G., Otto, J., Mitic, G., 2001. Thermo-mechanical properties and creep deformation of lead-containing and leadfree solders, in: Proceedings International Symposium on Advanced Packaging Materials Processes, Properties and Interfaces (IEEE Cat. No.01TH8562). IEEE, pp. 129-134. doi:10.1109/ISAOM.2001.916562

SEAI, 2014. Best Practice Guide Photovoltaics (PV). Sustain. Energy Auth. Irel.

Sinha, A., Sastry, O.S., Gupta, R., 2016. Nondestructive characterization of encapsulant discoloration effects in crystalline-silicon PV modules. Sol. Energy Mater. Sol. Cells 155, 234-242. doi:10.1016/j.solmat.2016.06.019 
Skoplaki, E., Boudouvis, A.G., Palyvos, J.A., 2008. A simple correlation for the operating temperature of photovoltaic modules of arbitrary mounting. Sol. Energy Mater. Sol. Cells 92, 1393-1402. doi:10.1016/j.solmat.2008.05.016

Skoplaki, E., Palyvos, J. a., 2009a. Operating temperature of photovoltaic modules: A survey of pertinent correlations. Renew. Energy 34, 23-29. doi:10.1016/j.renene.2008.04.009

Skoplaki, E., Palyvos, J.A., 2009b. On the temperature dependence of photovoltaic module electrical performance: A review of efficiency/power correlations. Sol. Energy 83, 614-624. doi:10.1016/j.solener.2008.10.008

Smith, D.R., Madeni, J.C., 2002. Properties of Lead-Free Solders. Electronics.

Syed, A., 2004. Accumulated creep strain and energy density based thermal fatigue life prediction models for SnAgCu solder joints. 2004 Proceedings. 54th Electron. Components Technol. Conf. (IEEE Cat. No.04CH37546) 1, 737-746. doi:10.1109/ECTC.2004.1319419

Syed, A., 2001. Predicting solder joint reliability for thermal, power, and bend cycle within 25\% accuracy. Electron. Components Technol. Conf. ... 255-263. doi:10.1109/ECTC.2001.927732

Vandevelde, B., Gonzalez, M., Limaye, P., Ratchev, P., Beyne, E., 2007. Thermal cycling reliability of $\mathrm{SnAgCu}$ and $\mathrm{SnPb}$ solder joints: A comparison for several ICpackages. Microelectron. Reliab. 47, 259-265. doi:10.1016/j.microrel.2006.09.034

Wang, Y.-W., Wu, M.-L., 2011. Failure of lead-free solder joint under thermal cycling, in: 2011 6th International Microsystems, Packaging, Assembly and Circuits Technology Conference (IMPACT). IEEE, pp. 265-268. doi:10.1109/IMPACT.2011.6117281

Wiese, S., Schubert, A., Walter, H., Dukek, R., Feustel, F., Meusel, E., Michel, B., 2001. Constitutive behaviour of lead-free solders vs. lead-containing solders-experiments on bulk specimens and flip-chip joints, in: 2001 Proceedings. 51st Electronic Components and Technology Conference (Cat. No.01CH37220). IEEE, pp. 890902. doi:10.1109/ECTC.2001.927900

Wong, E.H., Van Driel, W.D., Dasgupta, A., Pecht, M., 2016. Creepfatigue models of solder joints : A critical review. MR. doi:10.1016/j.microrel.2016.01.013

Woyte, A., Richter, M., Moser, D., Mau, S., Reich, N.H., Jahn, U., 2013. Monitoring of Photovoltaic Systems: Good Practices and Systematic Analyes. 28th Eur. PV Sol. Energy Conf. Exhib.

Xiao, H., Li, X.Y., Hu, Y., Guo, F., Shi, Y.W., 2013. Damage behavior of SnAgCu/Cu solder joints subjected to thermomechanical cycling. J. Alloys Compd. 578, 110117. doi:10.1016/j.jallcom.2013.05.026

Ye, J.Y., Reindl, T., Aberle, A.G., Walsh, T.M., 2014. Performance degradation of various PV module technologies in tropical Singapore. IEEE J. Photovoltaics 4. doi:10.1109/JPHOTOV.2014.2338051

Yuwawech, K., Wootthikanokkhan, J., Tanpichai, S., 2015. Enhancement of thermal, 
mechanical and barrier properties of EVA solar cell encapsulating films by reinforcing with esterified cellulose nanofibres. Polym. Test. 48, 12-22. doi:10.1016/j.polymertesting.2015.09.007

Zarmai, M.T., Ekere, N.N., Oduoza, C.F., Amalu, E.H., 2015. A review of interconnection technologies for improved crystalline silicon solar cell photovoltaic module assembly. Appl. Energy 154, 173-182. doi:10.1016/j.apenergy.2015.04.120

Zhao, J., Mutoh, Y., Miyashita, Y., Mannan, S.L., 2002. Fatigue crack-growth behavior of Sn-Ag-Cu and Sn-Ag-Cu-Bi lead-free solders. J. Electron. Mater. 31, 879-886. doi:10.1007/s11664-002-0199-z 